\title{
Socio-Political Conflict and Economic Performance in Bolivia
}

\author{
JOSE LUIS EVIA \\ ROBERTO LASERNA \\ STERGIOS SKAPERDAS
}

CESIFO WORKING PAPER NO. 2249

CATEGORY 5: Fiscal PoliCy, MACROECONOMICS AND GROWTH MARCH 2008

\footnotetext{
An electronic version of the paper may be downloaded

- from the SSRN website:

www.SSRN.com

- from the RePEc website:

Www.RePEc.org

- from the CESifo website:

www.CESifo-group.org/wp
} 


\title{
Socio-Political Conflict and Economic Performance in Bolivia
}

\begin{abstract}
We examine how socio-political conflict in Bolivia has affected its economic performance since the 1970s. Such conflict includes strikes, demonstrations, road blockades, and conventional rent-seeking. Since conflict has costs, it diverts resources away from production, tends to reduce investment and could therefore reduce economic growth. We first review the characteristics of conflict in Bolivia using a unique data set. We then provide estimates of the direct costs of conflict and examine the relationship with economic performance using hypotheses derived from a simple model. In particular, we make a distinction between economic growth that is due to external factors - like changes in income due to movements in the terms of trade - and economic growth that is due to productive investment. Growth due to external factors tends to be positively related to conflict, whereas growth due to productive investment should be negatively related to conflict. Finally, we discuss how levels of conflict, economic performance, and governance might be related in Bolivia's recent history.
\end{abstract}

JEL Code: D70, H10, O11, O54.

Keywords: economic growth, property rights, governance.

Jose Luis Evia

Catholic University of Bolivia \&

Andean University "Simon Bolivar"

jlaevia@acelerate.com

\author{
Roberto Laserna \\ CERES, Bolivia \\ laserna_r@yahoo.com
}

\author{
Stergios Skaperdas \\ Department of Economics \\ University of California, Irvine \\ USA - Irvine, CA 92697 \\ sskaperd@uci.edu
}

Revised: February 27, 2008

We would like to thank participants at the conference on Bolivia, held at the Kennedy School of Government in November 2006, for their comments, and especially Francisco Rodriguez for his detailed suggestions. For discussions and background information, we are also very grateful to Eduardo Antelo, Viviana Caro, Nathan Fiala, Horst Grebe, Gary Milante, Herbert Muller, Suresh Naidu, Oswaldo Nina, Henry Oporto, Guido Riveros, Jim Robinson, and Carlos Toranzo. 
Many existing approaches to understanding economic performance in low-income countries have not been very fruitful (see Easterly, 2001, for a critical review of the various approaches). With all the technological and organizational advances that have occurred over the past half century, let alone those advances that had taken place earlier than that, it would be difficult to understand the economic stagnation of countries like Bolivia if one were to rely solely on economic factors as explanatory variables.

It has therefore become increasingly evident that the incorporation of social and political variables, as well as economic ones, is crucial in improving understanding of economic performance. ${ }^{1}$ Recent research is pointing to the significant role of conflict (and the role that governance and institutions may play in reducing conflict) in determining economic performance. ${ }^{2}$ Bolivia has high levels of particular types of conflict that may well be distinct from those in other countries in the Americas. The conflicts are among unusually highly developed collective organizations -- organized along economic, regional, or ethnic dimensions -- that seek to improve their position through lobbying and influence, strikes, protests, and other forms of collective action. The state appears to have a limited capacity in containing these conflicts, although that capacity has fluctuated over the years.

In this paper we first describe the landscape of social and political conflicts in Bolivia, the main participating organizations and actors, and how these have evolved in the past few decades. We introduce a data set on conflicts in Bolivia since 1970 that has been constructed by Roberto Laserna, and which we employ in the rest of the paper.

We then examine how appropriative conflict, governance, and economic performance interact. In particular, we will argue that conflict in Bolivia affects economic performance in a number of distinct ways.

First, the different types of conflict have direct economic costs that take away resource from production, consumption, and investment.

\footnotetext{
${ }^{1}$ North (1990) has been an early advocate of the centrality of institutions in determining economic performance. Olson (2000) has been emphasizing the role of governance and power, whereas Greif (2006) provides a historical perspective informed by modern game theory. Acemoglu, Johnson, and Robinson (2005) have spearheaded the recent push in establishing the centrality of the social and political determinants of economic growth. An early precursor to such approaches who introduced the possibility of conflict and appropriation in modeling economic growth but who received almost no attention is Haavelmo (1954).

${ }^{2}$ In empirical studies, Rodrik (1999) has examined the effect of social conflict and the institutions that control conflict on economic performance, Easterly and Levine (1997) have assessed the role of ethnic divisions in Africa's low growth, Alesina et. al. (2003) have extended the analysis (but with ambiguous results), whereas Abadie and Gardeazabal (2003) have focused on the measurement of the differential performance between Basque regions and other regions of Spain. Hirshleifer (1989, 2001), Grossman (1991, 1996), Skaperdas (1992), Skaperdas and Syropoulos (2002) have allowed for the possibility of conflict in otherwise regular economic models and shown how resource allocation differs significantly from those in which conflict is not possible. Garfinkel and Skaperdas (2007) provide an overview of the literature. Miguel et. al. (2004) shows how exogenous shocks to growth induce conflict, whereas Collier et. al. (2003) synthesizes much research on civil wars and their relationship to economic development.
} 
Second, conflict changes the incentives that would normally be expected in a frictionless world of markets so that production, investment, and innovation are distorted in ways that significantly impinge on economic performance. How conflict and growth are related, however, depends on the sources of growth. Conflict and growth generated through investment are negatively related because of the aforementioned negative incentive effects associated with insecurity. Growth that is generated purely from external sources (for example, from changes in the terms of trade, or from official transfers from abroad) are positively correlated with conflict, as such external sources of growth tend to intensify rent-seeking and other types of appropriative competition.

Third, conflict and the levels of resultant economic activity affect investments in "institutions," "governance", or "property rights," which in turn affect future levels of conflict and economic performance.

We provide economic explanations, by either outlining or developing models that make these different points, and we offer some preliminary evidence in support of some of the hypotheses that we develop. In Section I we present the different dimensions of socio-political conflict in Bolivia, introduce the data set on conflict, and make some preliminary assessment of the effects of conflict. In section II we develop a simple model that relates the two different types of growth to levels of conflict and develop hypotheses that we examine in section III, where we present estimates of the direct and some spillover costs of conflict as well. Section IV concludes.

\section{Social and Political Conflict in Bolivia}

The types of conflicts that have been taking place in Bolivia are qualitatively different from the violent conflicts and civil wars that have taken place in many low-income countries since World War II (see Collier et al, 2003), including those in Latin American countries like Colombia. In Bolivia, conflict takes the form of protests, strikes, boycotts, road-blocks, and other similar "appropriative" activities that are undertaken by well-organized groups. The influence of government policies through other political channels that may not involve any overtly observable appropriative activities also takes place. What is probably unique among other Latin American countries (and perhaps most other low-income countries as well) is the very high level of collective organization of various groups along economic, regional, or ethnic dimensions. $^{3}$

\section{I.A On the different dimensions of conflict}

\section{Economic dimensions and cleavages}

\footnotetext{
3 This high level of collective organization could be part of the legacy of the active efforts in encouraging such organization that lead to the nationalist revolution in the 1950s, which in turn promoted grassroots organizations in order to favor participatory populist politics over formal democracy. See Lora Guillermo 1967-1980, Dunkerley James 1991, Lavaud Jean Pierre 1998, Calderón and Smukler 2000.
} 
Obviously, collective organizations that articulate economic interests are central actors in the types of conflicts that exist in Bolivia. They include ordinary workers' unions, associations and cooperatives, as well as business groups.

Unions include the Confederación de Trabajadores en Salud (Health worker's union), the Confederación Sindical de Maestros (Teacher's union), and the Central Obrera Boliviana (COB) (see Table X.1 in Robinson, 2005). In addition, self-employed taxi, microbus, bus, or truck drivers have their own associations, just as cocaleros and miners do. Furthermore, both wage workers (Federación Sindical de Trabajadores Mineros) and individual, small entrepreneurs organize in cooperatives (FENCOMIN). These unions and associations have instruments of public pressure that could be categorized as appropriative and include demonstrations, strikes, work stoppages and road blockades.

Business groups include the Confederación de Empresarios Privados de Bolivia $(C E P B)$ and its nine departmental Federaciones, the regionally-oriented Cámara de Industria, Comercio, Servicios y Turismo de Santa Cruz (CAINCO), and special entrepreneurial Cámaras in every department grouping industrial, commerce, construction and other sectors (again, see Table X.1, in Robinson, 2005) as well as more informal groupings one could find within other organizations, from political parties to civic clubs and associations. Such groups have influence through the credible threat of stopping to pay taxes (as argued in Robinson, 2005, an instrument however which seldom has been used), their connections with politicians, or their partial ownership of media.

\section{Regional Cleavages}

City or regional associations (Comités Cívicos and Juntas Vecinales) have been important independent actors in policy determination. They were usually founded as voluntary organizations of the elite to promote modernization in the first half of the $20^{\text {th }}$. Century, but gained momentum during the national revolution of the 1950's when the Santa Cruz committee managed to claim a permanent, proportional share in hydrocarbons exploitation: an 11\% royalty on the production value of hydrocarbons for the region ${ }^{4}$. Public investment decided by regional authorities and funded with royalties soared in the region and partially explains the rapid economic growth of Santa Cruz, which became somewhat of a model for other regions.

During military governments, civic committees established themselves as participatory channels, developing consensus building practices within the regions and negotiating public works and, in some cases, policies, with the government ${ }^{5}$.

Cochabamba, Tarija, Chuquisaca, Beni, Potosí and other regions or cities like El Alto organized civic associations capable of mobilizing their constituents for demonstrations, strikes, road blockades as well as for less overt forms of political action. Such civic association action has been instrumental in the past two presidents of the country losing their office.

\footnotetext{
${ }^{4}$ Roca (1980) reads the Bolivian history as produced through regional conflicts and Calderón and Laserna (1984) collected analysis of the contemporary role of regional movements.

${ }^{5}$ See Laserna (1986).
} 
The discovery of sizable hydrocarbon deposits in Tarija and the existence of a relatively more developed market economy in the Eastern part of the country, the socalled "half-moon" states (Pando, Beni, Santa Cruz, Tarija), has created in the last years tensions with the central government in La Paz and other more centralist, state dependent regions, regarding the policies of exploitation and use of the benefits of these deposits, and the more general institutional structure of the country. Regions with more defined identity as such and a stronger civic organization demand more decentralization in the form of autonomous states.

The civic groups and associations are playing, and can be expected to continue to play, prominent roles in the staking of positions and political maneuvering so as to be in better bargaining positions.

\section{Ethnic dimensions}

Another dimension that can be a source of contention is that of ethnicity. The main cleavage that could be identified is that between indigenous communities and what is perceived as a Spanish-derived culture. Organizations like the Confederación Sindical Unica de Trabajadores Campesinos Tupac Katari (CSUTCB), the Confederación de Indígenas del Oriente Boliviano (CIDOB) and the National Council for indigenous communities (Consejo Nacional de Ayllus y Markas del Qollasuyo) exert political pressures through demonstrations and road blockades, developing an ethnic identity against what they call internal colonialism that would have continued during the republic and after independence from Spanish colonial rule (1825) ${ }^{6}$.

For a long time in Bolivia, the class divisions were almost coincidental with ethnic divisions. There was an overlapping whereby the poor were mostly indigenous, the upper classes were mostly white and in between, as the real middle class integrated by truck drivers and middlemen, were the mestizo or cholo groups. This overlapping was reinforced both by discriminatory policies aimed to the economic exploitation of the indigenous labor force that were put in motion during colonial times, but also by successful movements of cultural resistance that lead to the official recognition of specific areas where indigenous groups were capable of preserving their traditional institutions, albeit at the cost of isolating them from the process of modernization with subsequent disadvantages for the participation of members of the group in the market economy and urban life ${ }^{7}$.

The coincidence among the two structures of social differentiation started to crumble after the Nationalist Revolution of the 1950s. The agrarian and educational reforms opened processes of urbanization and social mobility that changed dramatically the economic structure, removing partially the economic "explanations" of ethnic differentiation and discrimination. When some cholos, quechuas and aymaras became wealthy, they realized that exclusion was not only economic but also cultural, while at the same time those at the lower levels were able to see that being indigenous should not inevitably mean being poor. In both cases, ethnic cleavages became more visible and easy to perceive, so that appealing to them made viable the development of politics of identity and the emergence of ethnic movements. Paradoxically, when

\footnotetext{
${ }^{6}$ See particularly Calderon and Dandler (1984), Rivera (1984) and Hurtado (1986).

${ }^{7}$ See Albo and Sandoval (1981), Loayza (2004), Laserna (2005).
} 
structures of discrimination began to change, ethnicity became a hot political issue and a source of major tensions in Bolivia.

Simplistic views on Bolivia, exposed in the political discourse of the emerging groups and uncritically accepted in the media, tend to forget the long history of ethnic mixture within indigenous groups and between them with Western groups. The "mestizaje" was an accepted policy during most of the Colonial period and was officially promoted during the national revolution with the support of social movements, in an attempt to create a unified, national culture and to expand political and economic participation through educational, agrarian and electoral reforms. The objective of empowering indigenous groups was so successful that lead some of them to a more radical belief: that they do not need to share power, but to control it and recover what has been supposedly lost during the past five centuries. The risk of ethnic conflict arose basically from this way of understanding the issue, which is not general but it is certainly powerful to mobilize feelings of resentments and revenge.

Besides overt political pressures, pre-existing or constructed differences in ethnicity can reduce productivity in the workplace, and if widespread can impinge of economic performance. $^{8}$

Lobbying and rent-seeking in the proverbial smoke-filled room is another form or activity that remains covert and almost impossible to measure. What has been measured in Bolivia are different types of overt conflictual activities, in the data set collected by one of the authors.

\section{I.B Description and preliminary analysis of Bolivian conflict data}

The data on conflict has been systematically collected from the most important national newspapers from January 1970 up to the present ${ }^{9}$. They allow a comprehensive understanding of social conflict in Bolivia, while providing quantitative indicators of social disruption, participation, motives and tools used to exert pressure on governments and the rest of the population.

Every collective event was recorded in a form where the event is described with a phrase, the main and secondary participants are identified as well as the adversary as defined by the protest leaders. The duration and results of the event are also recorded, as well as other variables such as place, dates, coverage and so on. Since the data come from newspapers, not all have the same information so that the information is

\footnotetext{
${ }^{8}$ Gellner (1983) has described nation-building as a process of cultural homogenization that essentially plays the role of homogenizing labor for ultimately economic purposes. In the absence of such homogenization, communication and collaboration within the modern workplace becomes difficult according to Gellner, and reduces overall economic performance.

${ }^{9}$ There have always been at least three major newspapers, one from each of the main Bolivian cities. In La Paz we started with Presencia and moved to La Razon when the first ceased publication. In Cochabamba with Los Tiempos and in Santa Cruz with El Deber. The same forms and definitions have been used for the whole time to make sure that the data, no matter when is collected, remains compatible. Before coding the forms, they are compared and the information completed, making sure that each event is registered only once. Not all conflictive events reach the newspapers and we found that the highest the frequency, the greater the proportion of small conflicts not registered in the media. This means that estimates based on this data base are conservative, but analysis based on long term trends are quite accurate.
} 
compared, contrasted and complemented so that the data is polished and refined with one data sheet per event. Once the forms have been completed and duplications discarded, the information is codified and introduced in the computer.

An event is a social, collective action that disrupts production, trade, transportation or the delivery of public services, including the proper functioning of institutions by infrastructure takeovers or sit ins. Therefore, for analytical purposes it must be remembered that a social conflict is not only an event such as the one recorded, but may be expressed by one event or by a chain of events, involving one or many groups. For a deeper understanding of a specific social conflict, the data base is clearly insufficient. It is, however, valuable to grasp lasting conjunctures and for quantitative analysis.

The data set used in this paper contains information on 11247 events registered between January 1970 and September 2006, in 17 variables plus aggregations that can be made for analytical purposes. There were 25.5 events registered per month during the 441 months covered so far by the data, but the number of events varied considerably from none in some very repressive periods to more than 90 during the first post authoritarian government. In this paper we will use this data base mostly aggregating data per year up to 2005, so that periods will match those used in economic statistics. The following graph, displaying conflictive events per year, provides a first glimpse of the past few decades.

Figure 1. Bolivia: Number of social conflicts per year. 1970-2005

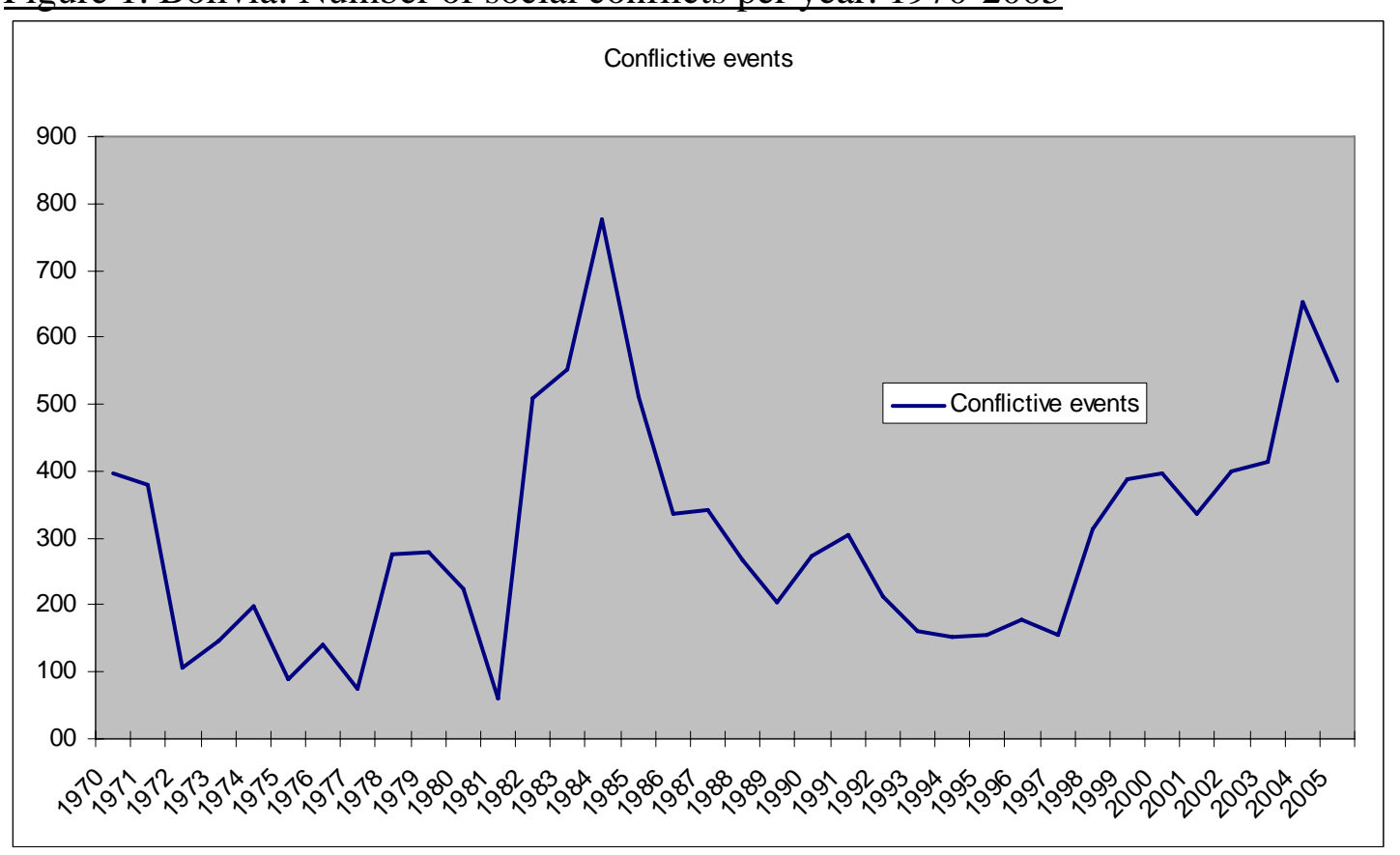

Source: Social Conflicts Watch Program- CERES (Bolivia)

After a period of political instability, in August 1971 a faction of the army took control of the government abolishing civil liberties until 1978, when social protests and international pressures forced general elections. This period coincided with an improvement in the terms of trade that enabled Bolivia to achieve an average rate of growth of $5.5 \%$. 
During these years GDP increased and the number of conflicts decreased. Although there could be a relationship between growth and the reduction of the number of conflicts, the abolition of civil liberties in a non democratic regime is a relevant explanatory factor in the low number of conflicts in this period, since political parties and unions were banned and thousands of leaders and intellectuals fled to exile. Also the acute increase in conflicts at the end of the seventies could be explained by political reasons: the struggle for democracy and civil liberties. But also the growth of output in the seventies could have engineered a struggle for the distribution of income that was masked and presented as a struggle for democracy.

The period between 1978 and 1982 was one of social unrest, frustrated elections and coups d'etat, in which nine civilian and military governments alternated in government. This period ended with the democratic transition, when a civilian coalition of leftist inspiration took office. The return to democracy unleashed social claims, which the government was unable to control. The deterioration of the world economy, natural disasters that affected agricultural production and high levels of social conflict generated a hyperinflation that forced the government to shorten its period, calling for early elections in 1985. The average rate of growth between 1978 and 1985 was minus $1.1 \%$.

In these years of social instability and short term governments, declining output accompanied increasing social conflict. The inverse relationship between conflict and growth could be understood differently, depending on the direction of causality. The fall in output could induce increasing social conflicts. But there also could be the possibility that the pattern of more conflict and less output was the outcome of the previous period: the increase of output generated a distributive fight, which damaged growth. The economic crisis that emerged reduced output, and ended the distributive conflict: growth may contain the seeds of its own destruction. If this is the case, this has strong implications for growth in Bolivia: growth could only be sustainable if it spreads its benefits to the whole society.

In 1985 a new government took office and implemented its "New Economic Policy”, liberalizing most of the productive and service activities, and pushing for an open market economy. This period of democracy and market oriented economy, ended in 2003, when the president was forced to leave the country in the middle of a violent turmoil. In this period the average rate of growth for the Bolivian economy was of $3.5 \%$ and, until 1997, the levels of conflict declined. To what extent growth could explain the reduction of conflicts between 1986 and 1997 or the reduction of conflicts could explain growth? The relationship reversed from then on with increasing conflict and social instability, as well as declining growth ${ }^{10}$.

Going back to the data shown in figure 1, there are two periods with low conflict and high peaks in 1970, 1985 and 2004, being the second low-conflict period longer than the first. A major difference between those two periods lies in the political regimes ruling those periods. While the first was mostly run by the military (1970 to 1982, with disruptions and several coups d'Etat), the second was fully democratic, with free elections to renew governments and parliament operating uninterruptedly.

\footnotetext{
${ }^{10}$ For a review of the whole period see Laserna (2004).
} 
The least intense year was 1981, soon after the military interrupted a democratic opening and imposed a violent authoritarian regime, closely tied with drug trafficking $^{11}$. And the highest peak corresponds to 1984, when there was an escalation of conflicts and mobilizations that, at the end, shortened the Siles Zuazo government by one year.

After general elections, Congress appointed Paz Estenssoro as President in 1985, starting a process of structural adjustment and institutional reforms that introduced profound changes in the country during the immediate terms of Jaime Paz and Gonzalo Sánchez de Lozada. In a way, this process was interrupted when Gen. Banzer, the military ruler of the 1970's, was elected in 1997. As can be seen in the graph, the number of conflictive events immediately skyrocketed in a trend that continues well into the 2006, hampering governance and weakening democratic institutions. At the end of 2003 President Sanchez de Lozada, elected for his second term in 2002, was forced to quit, and the same happened to his successor, the former Vice President Carlos Mesa, by the middle of 2005. The number of events declined a little during the short administration of Eduardo Rodriguez, the Justice who was appointed by Congress in June 2005 to preside over anticipated elections which took place in December. Evo Morales, a peasant leader from the coca region of Chapare won by a landslide, promising to give the State control over natural resources and to “reverse internal colonialism”. His administration began in January 2006 and therefore it is left out of the scope of this paper.

Based on what is shown in the graph and what is known of the political process, it seems clear that when the military ruled, the number of conflicts signaled how open or closed was the regime to political participation, channeled mostly by overt social actions. When there was civilian rule, the number of conflicts signals the weakening of institutional governance, implying a declining capability of representative bodies to manage social and political conflicts. In both cases, the growing number of conflicts can be considered an indicator of a reduced capability of the Executive branch to implement public policies.

The more active groups are from the middle classes. As can be seen in the following table, protagonists of the largest percentage of events were public employees followed by students, urban teachers and university employees.

\footnotetext{
${ }^{11}$ Gen. Luis García Meza was condemned to 30 years in prison, and Cnl. Luis Arce Gómez, his Interior Minister, was sentenced to jail in the United States for drug trafficking. Both are in jail.
} 
Table 1. Leading Groups in social conflicts 1970-2005

\begin{tabular}{|c|c|c|}
\hline & Frequency & Percent \\
\hline No information & 20 & .2 \\
\hline Mining workers & 532 & 4.9 \\
\hline Manufacturing workers & 421 & 3.9 \\
\hline Construction workers & 135 & 1.2 \\
\hline Other manual workers & 223 & 2.0 \\
\hline Traditional peasants & 543 & 5.0 \\
\hline Cocalero peasants & 210 & 1.9 \\
\hline Urban neighbors & 513 & 4.7 \\
\hline Housewives & 69 & .6 \\
\hline $\begin{array}{l}\text { Handicrafters - self employed manual } \\
\text { workers }\end{array}$ & 36 & .3 \\
\hline Rural teachers & 195 & 1.8 \\
\hline Urban teachers & 612 & 5.6 \\
\hline Banking employees & 260 & 2.4 \\
\hline Students & 1039 & 9.5 \\
\hline Professionals & 196 & 1.8 \\
\hline Public employees & 1651 & 15.1 \\
\hline University employees and teachers & 444 & 4.1 \\
\hline Private entrepreneurs & 288 & 2.6 \\
\hline Petty traders & 222 & 2.0 \\
\hline Transportation drivers & 315 & 2.9 \\
\hline Political militants & 179 & 1.6 \\
\hline Citizens in general & 825 & 7.6 \\
\hline Unemployed - fired workers & 282 & 2.6 \\
\hline Veterans - retired workers & 176 & 1.6 \\
\hline Other groups & 744 & 6.8 \\
\hline $\mathrm{COB}$ & 320 & 2.9 \\
\hline COD & 322 & 3.0 \\
\hline Indigenous - native & 60 & .6 \\
\hline Cívic organizations & 68 & .6 \\
\hline Total & 10900 & 100.0 \\
\hline
\end{tabular}

Source: Social Conflicts Watch Program- CERES (Bolivia)

Aggregating those figures in fewer categories, the following chart shows predominance of middle classes in the whole period. 


\section{Leading groups (aggregated)}

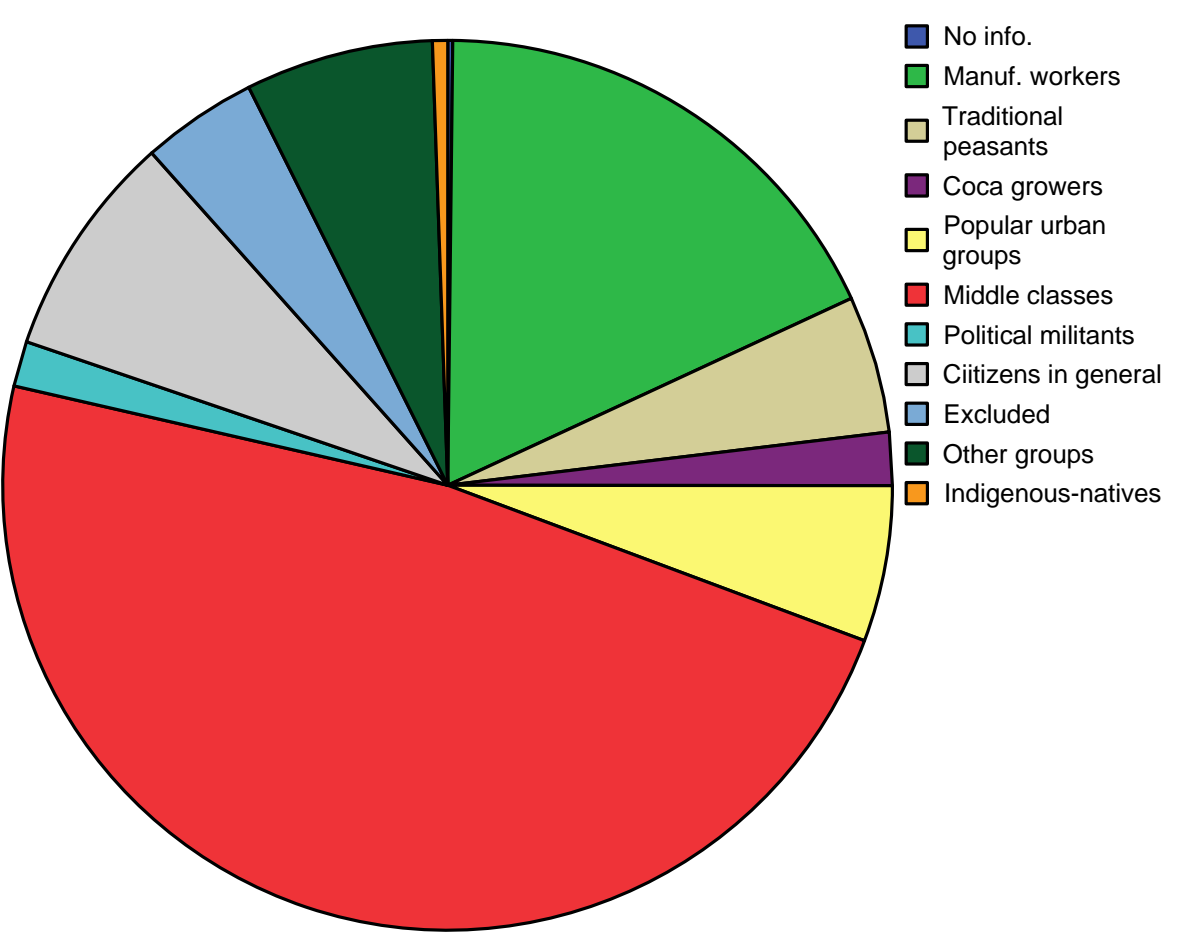

Source: Social Conflicts Watch Program- CERES (Bolivia)

However, it is interesting to notice a major change during the last years (see figure 3). When we differentiate the leading groups of conflictive events in just two categories, formal and informal, based on the type of institutional linkage they have, we can see that informal workers, both rural and urban, gained in importance since 1998, being responsible of the majority of events in the last year of the period. 
Figure 3. Trends in the participation of social groups in conflict 1970-2005

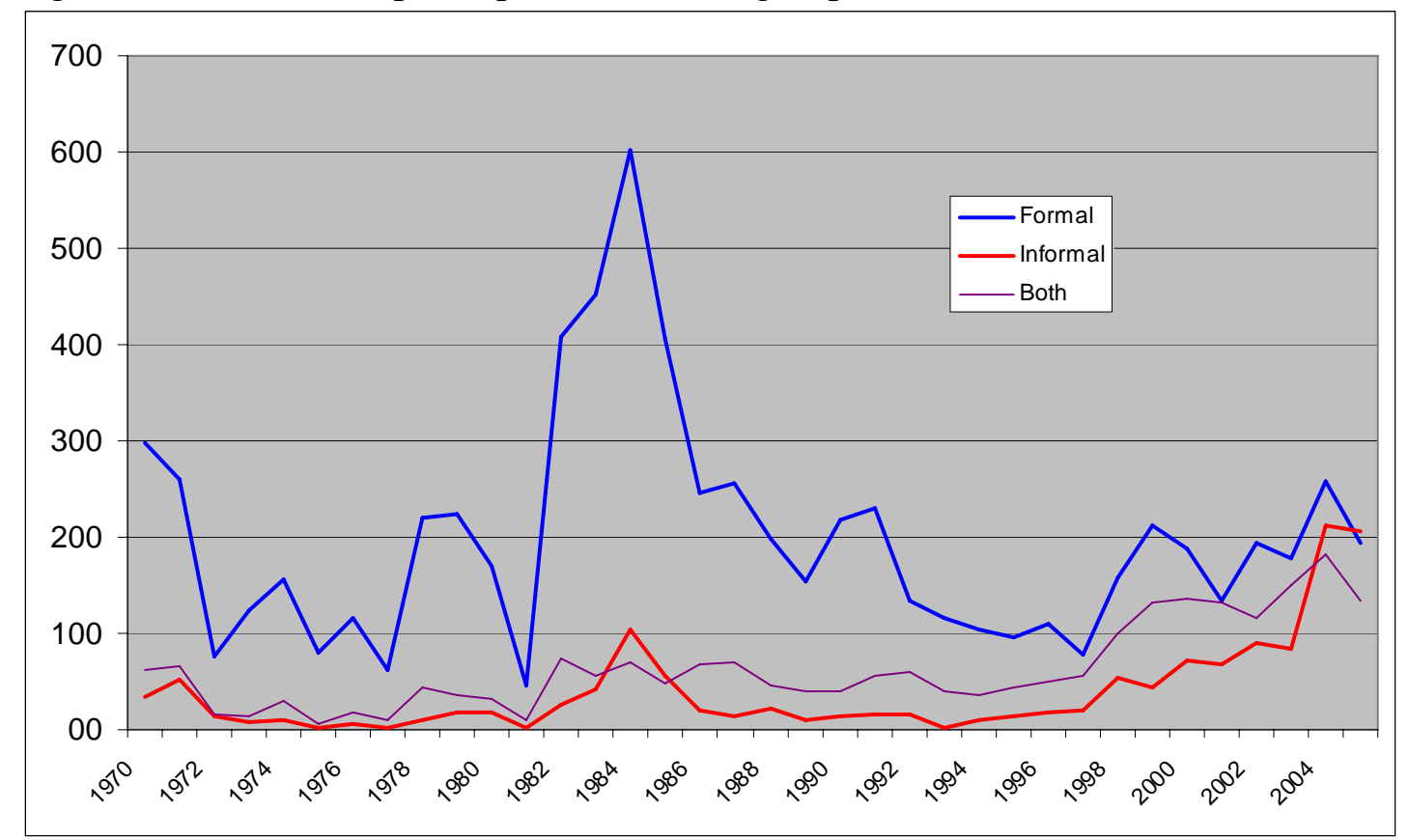

Source: Social Conflicts Watch Program- CERES (Bolivia)

The same trend is observable for groups that cannot be defined in those terms, either because they include both or because their main identity prevents classifying them in terms of formality. What is clear is the declining relevance of social actors linked to the formal economy and the institutional system, which is also signaled by the reduced importance of traditionally powerful organizations, such as the Central Obrera Boliviana and the Federación de Mineros. In fact, the latter being the backbone of the labor movement in Bolivia, it had the power to impose policies and ministers to friendly governments, and often also to prevent coups or topple governments they deemed adversarial. The political system between 1932 and 1985 was dominated by the interplay between the Army and the labor unions. It all started in the Chaco war and remained until the economic and political crisis of the 1980's, when hyperinflation reached a record and the population expressed demand for order $^{12}$.

In that sense, the current wave of conflicts is very new. Not only because the nature of the main actors (informal workers, citizens, rural peasants) but also because the arena where it is taking place is quite different.

Democracy is no longer a novelty, as it was for most of the people in 1982, but a regularity. State owned companies were privatized and the fiscal budget was expanded, mostly dedicated to social expenditures. A big part of it was also decentralized in more than 300 municipalities and 9 state governments (Prefecturas). The tin crash of 1985 determined the closure of big State owned mines and an aggressive plan attracted foreign investments to the hydrocarbons sector, placing Bolivia at the core of the energy market in South America and completely changing the structure of international trade. In the meantime, a market-led economy continue its development in the Eastern part of the country, with a dynamic agriculture

\footnotetext{
${ }^{12}$ See Malloy (1989), Klein (1968), Zavaleta (1970).
} 
producing industrial inputs like soy beans, cotton and sugar cane, and the agricultural frontier for the peasantry expanded towards the lowlands, supported by the insatiable cocaine market and, paradoxically, by the "alternative development" efforts to control drug trafficking ${ }^{13}$.

Therefore, the conflict peaks detected in the plotted series took place in very different scenarios and the shown trends also express those changes. In the following graph, for instance, even though urban conflicts are still dominant, the rural dwellers are leading a growing proportion of events, which demonstrates greater and stronger organizations, in spite of the declining demographic relevance of rural areas.

In the same figure 4 it is also possible to see that the number of events covering a whole department or the whole country have also declined, making visible the process of fragmentation in the social action scene. Conflictive events tend to be smaller, more particularistic and harder to reach political aggregation, contrary to the case in the 1970's and 1980's.

Figure 4. Trends of rural/urban participation in social conflicts. 1970-2005

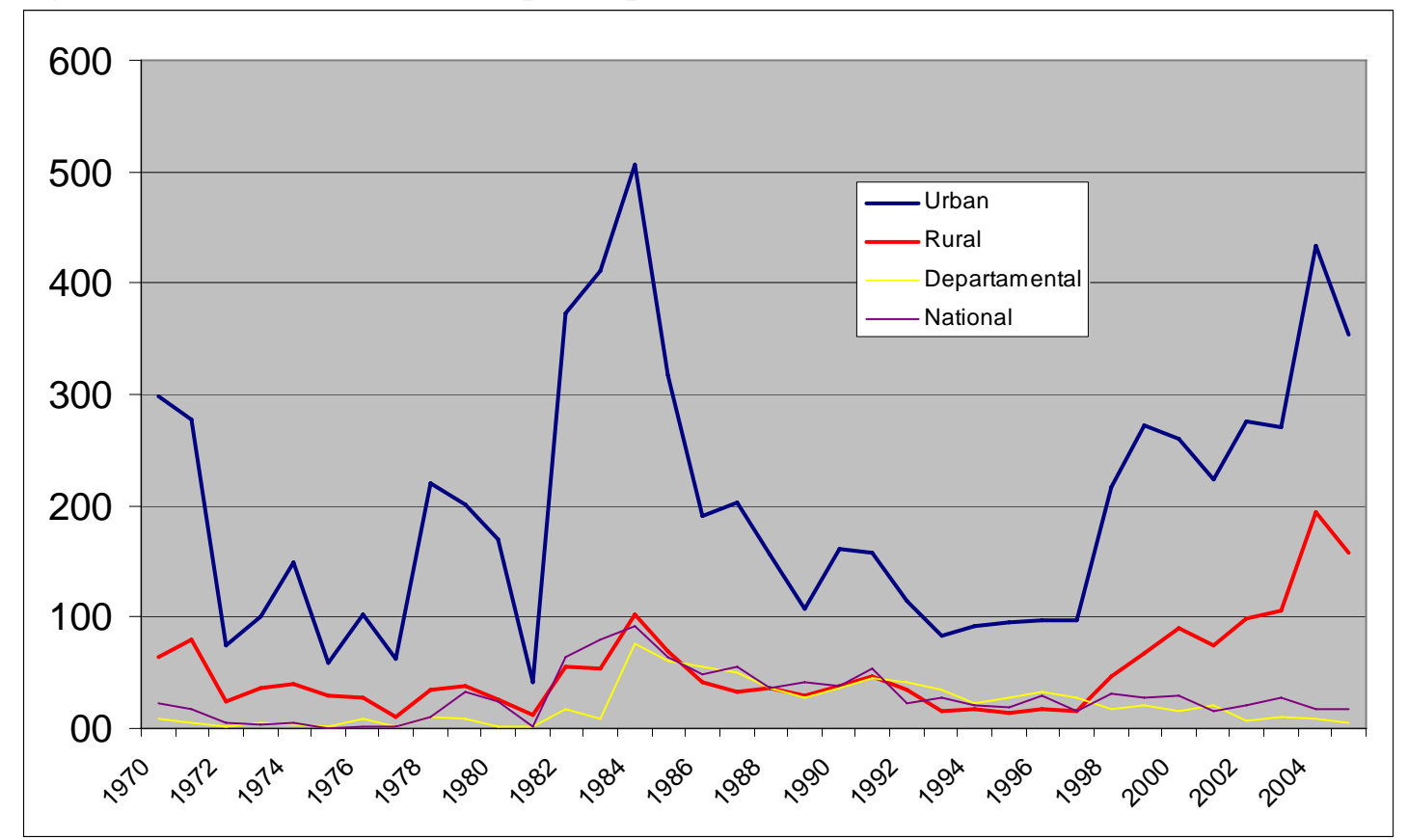

Source: Social Conflicts Watch Program- CERES (Bolivia)

But smaller and particularistic events, lead by fragmented groups, do not mean that they are less disruptive. It may be the opposite.

\footnotetext{
${ }^{13}$ Coca leaves production in Bolivia is part of a diversified, domestic economy of small peasants. They are, of course, trying to take advantage of high prices but also are stimulated by the seemingly endless market and the agricultural features of coca cultivation (a permanent plant that allows for three to four crops a year and is resistant to plagues and soil depletion). However, it is very unusual to find peasants dedicated only to coca cultivation, since most emphasize risk reduction more than economic profit. Alternative development projects made the coca areas the most attractive due to the concentration of public investments there. See Sanabria (1993), Laserna (2000).
} 


\section{Main form of action}

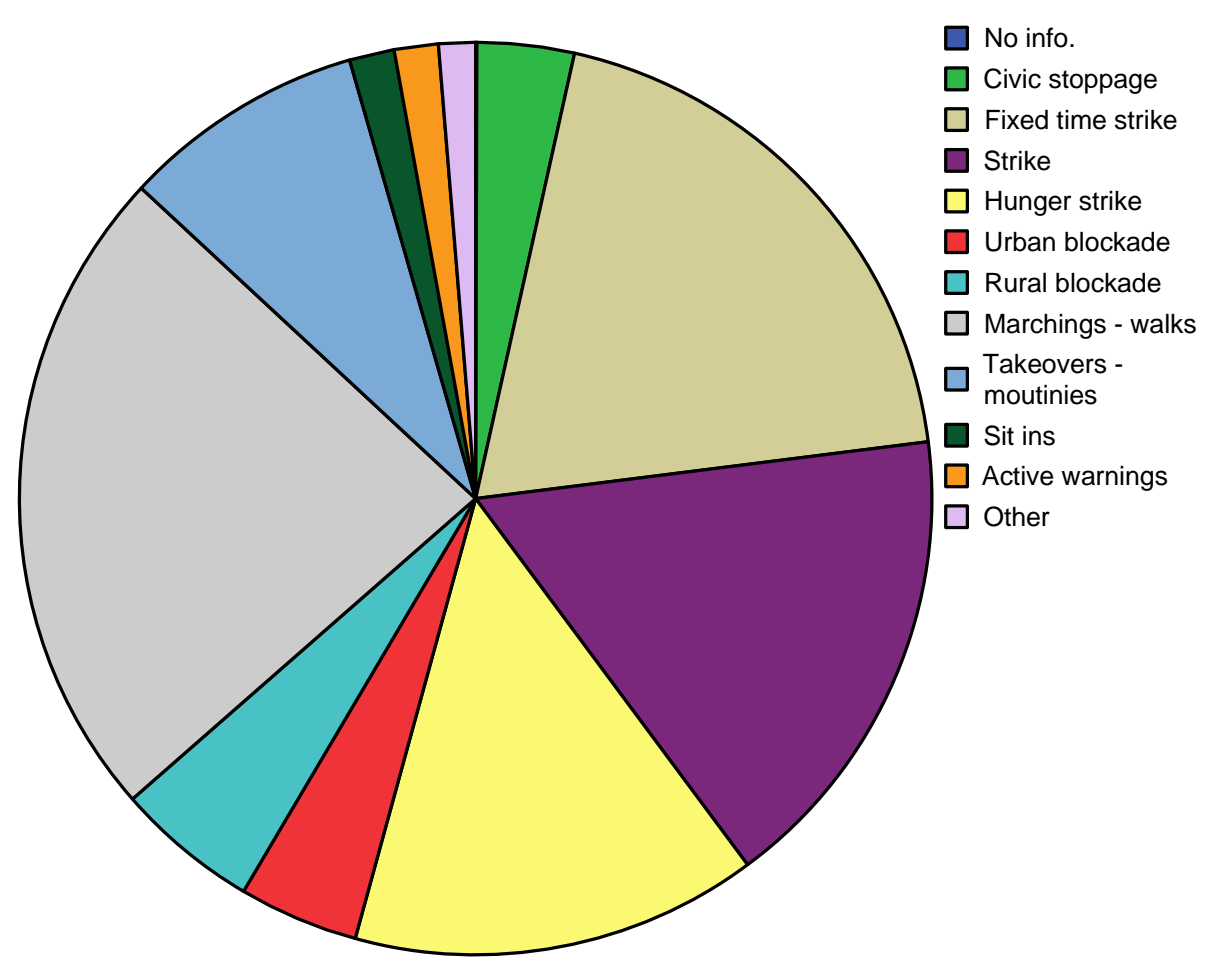

Source: Social Conflicts Watch Program- CERES (Bolivia)

As the previous chart describes, there is a wide variety of pressure tools used in conflictive events. The more frequent are labor strikes, public demonstrations and hunger strikes, but the number of blockades and takeovers is also very high.

When we aggregate the events in wider categories, an interesting picture of the trends emerges.

In fact, events may be differentiated according to the required behavior of the participants. We call "active" those types of actions that demand from the participants to do something different from their normal, regular daily life activities. And we call "passive" those events in which the participants are required to stop doing something that is usual and common for them. A road blockade and a demonstration are "active" events, while a labor strike or a civic stoppage are "passive” events. Of course, during a civic stoppage there may be a blockade, as during labor strikes there may also be demonstrations. In our database they are registered as secondary manifestations, leaving the dominant one as the main characteristic of the event.

The following figure 6 plots the whole series aggregating events in just two categories: passive and active events. 
Figure 6. Trends of aggregated types of conflict. 1970-2005

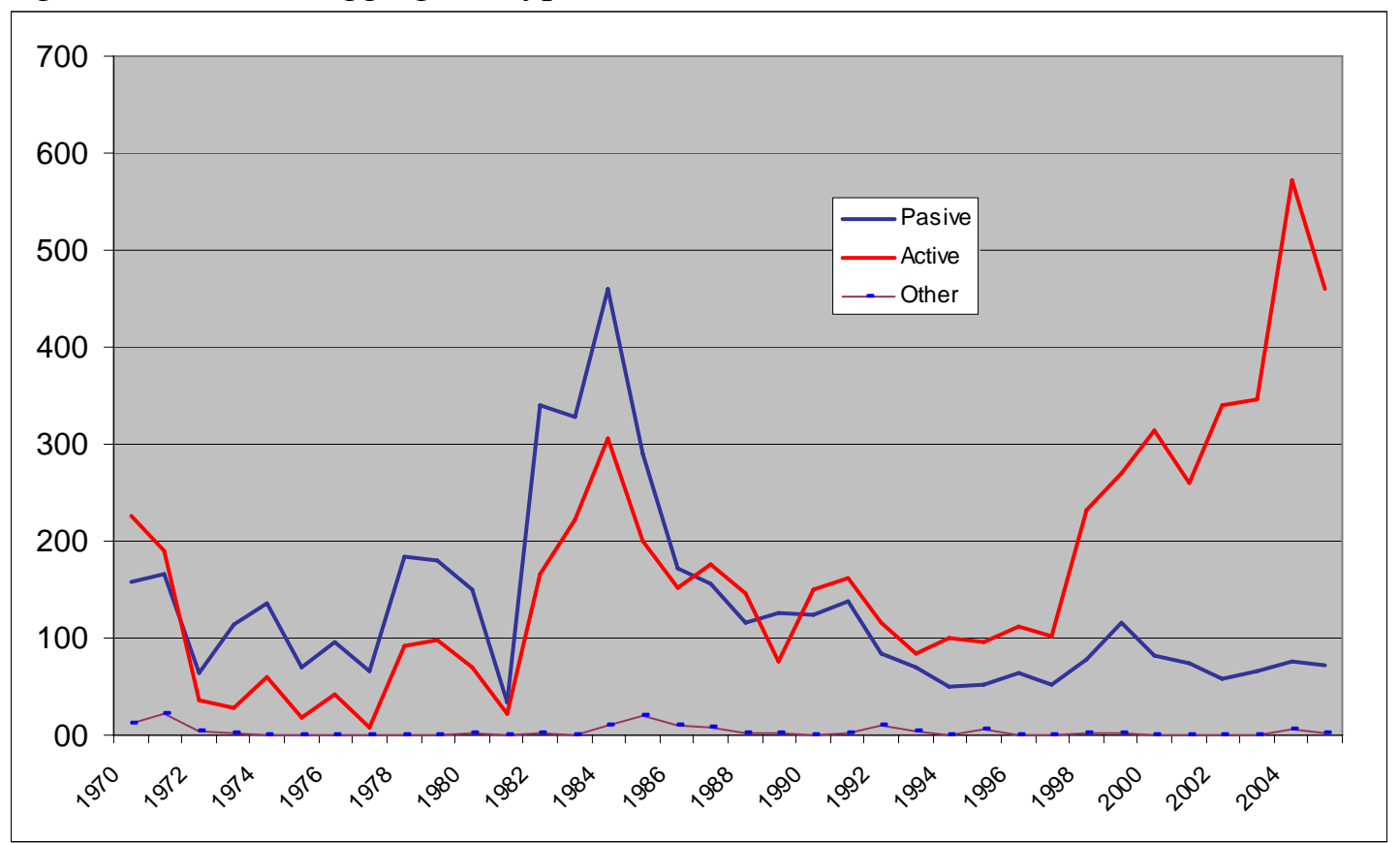

Source: Social Conflicts Watch Program- CERES (Bolivia)

It is easy to see a major change in the declining relevance of passive events and the growing importance of active events. In absolute terms, there are more active events now than there were passive when these were dominant.

This means that social conflicts may now be more disruptive because they are not confined to the labor place but take the streets and affect the lives of many more people that are unrelated to the matter of conflict. Because of that, the risk of violence is greater in active events. Some of them are, in fact, violent, since they impose a disruptive situation on the rest of the population. Road blockades, for instance, can be described as a type of hostage taking since the actors are putting pressure on innocent civilians to obtain something from the adversary, whether it is the government or a private company. Active events usually try to hit or to involve a third party in a conflict between two, which implies some level of violence over third parties. Not surprisingly, there are often clashes between the acting group and the general population. Clashes may end up with people injured or even dead. These risks are even greater when governments refuse to intervene or to regain control of the public spaces used in active events ${ }^{14}$.

\section{I.C. On the Politics of social conflict}

\footnotetext{
${ }^{14}$ During the last years, the Banzer (1997-2001), Mesa (2003-2005) and Morales (2006) governments made explicit vows not to use repression in social conflicts, in an attempt to gain or to preserve popularity while making concessions to appease the conflictive groups. As we will see, this policy backfired, encouraging more and more conflicts since the costs or risks of being part of them declined. Before Banzer quitting due to a fatal ailment, there were already voices asking for his resignation, and Mesa was actually forced to resign in the middle of a social upheaval. Morales' popularity, immense at the beginning, has been declining as social conflicts arise, but his fate may certainly be different. Sanchez de Lozada's second term (2002-2003) was interrupted by social conflicts even though he tried to keep control by using the Police and the Army, when fragmentation and internal conflicts had been already eroding those institutions just as the rest of the government institutions.
} 
Which are, according to our database, the motivations and immediate causes for social conflict in Bolivia? There are two variables that should provide a clue: the explicit goals of the leading groups, provided that their official discourse is to be trusted, and the adversary towards whom they address their actions and pressures. Table 2 shows the first.

Table 2: Main objectives

\begin{tabular}{|l|r|r|}
\hline Issues & & Percent \\
\hline No information & 29 & .3 \\
Civil rights and freedom & 393 & 3.6 \\
Human rights - legal justice & 302 & 2.8 \\
Rule of specific laws & 577 & 5.3 \\
Demanding or rejecting nominations & 715 & 6.6 \\
and appointment of authorities & 124 & 3.1 \\
Participation in management & 360 & 1.1 \\
Expropiation of properties & 1067 & 3.3 \\
To change laws and norms & 76 & 9.8 \\
In support of the Govt. & 1052 & .7 \\
Rejecting Govt. auth. Or its policies & 739 & 9.7 \\
Public works for the area & 380 & 6.8 \\
Consumption conditions & 395 & 3.5 \\
Labor conditions & 1224 & 3.6 \\
Wage increases & 1258 & 11.2 \\
Wage payments & 500 & 11.5 \\
Labor stability & 253 & 4.6 \\
Organizational - factional conflicts & 402 & 2.3 \\
Solidarity with third parties & 642 & 3.8 \\
Demanding support to a specific & 412 & 3.7 \\
company or institution & & 5.9 \\
Other & & 300.0 \\
Total & & 2900 \\
\hline
\end{tabular}

Source: Social Conflicts Watch Program- CERES (Bolivia)

Looking at the main explicit goals, as described in the table, the largest proportion of events were related to wages (22.7\%), followed by more specific demands to participate in nominations or in support of the institution or company. A big proportion of conflicts, almost $20 \%$, were related to public policies or governmental decisions considered to be harmful for the leading group, although often its discourse refers also to "the nation" or "the people".

Crossing this variable with the one that identifies the adversary as defined by the leading group, it is clearly observable a dominance of corporatist goals (see crosstab in the annex). Thus, the fusion of social actors, political parties and the State is verified by the data, which according to Touraine would be a basic characteristic of corporatist populism ${ }^{15}$.

\footnotetext{
${ }^{15}$ See Touraine (1987), pp. 12 - ss.
} 
A summary of the adversary towards whom a social pressure is addressed shows that the State is the main subject of conflict. When combining with other public institutions, like municipalities or public companies, almost $90 \%$ of events were directly related to the State. Of course, most were not "against" but "towards" the State, claiming participation or, perhaps more clearly, integration into the political process.

Figure 7. Identified adversaries in social conflicts. 1970-2005

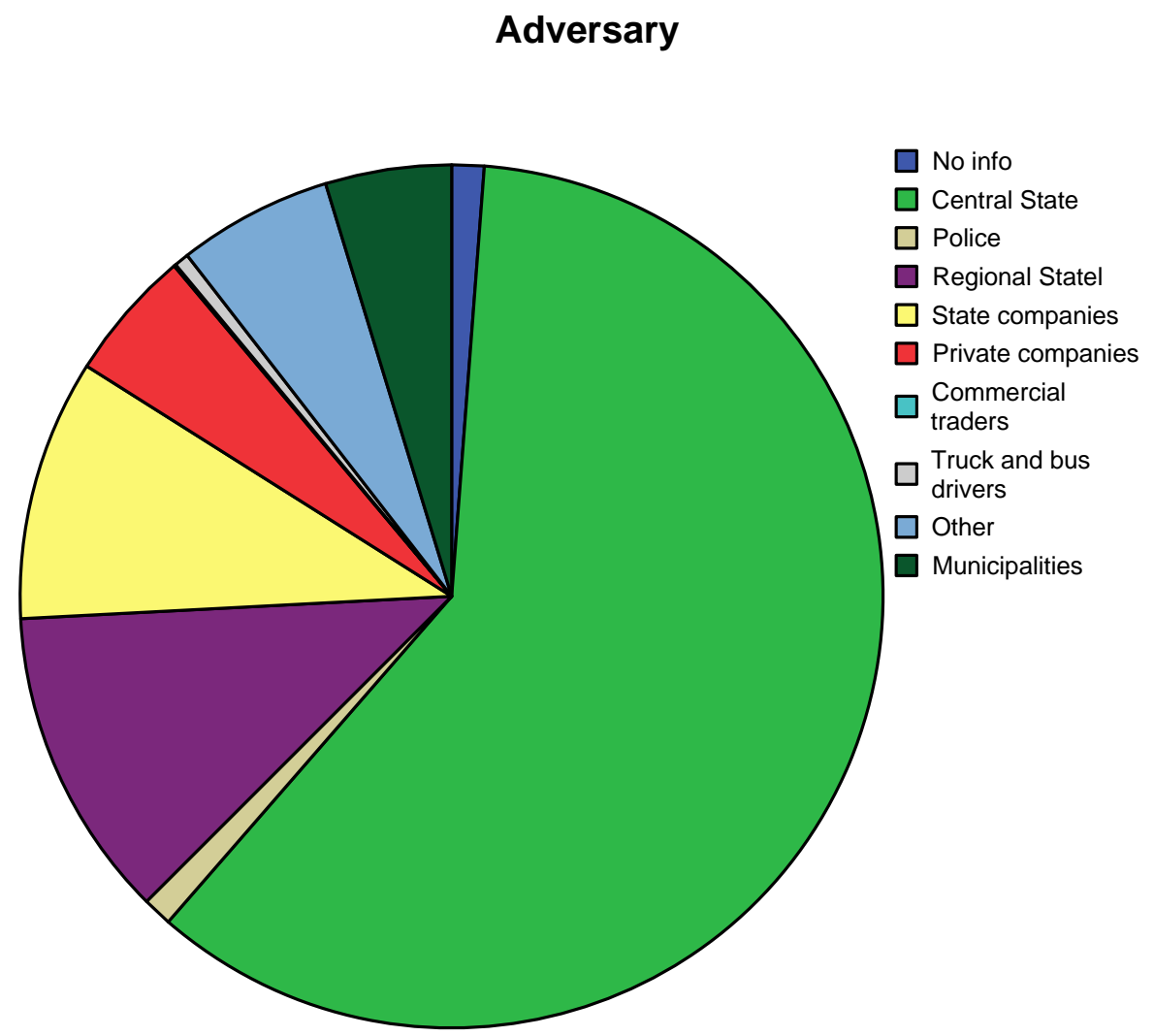

Source: Social Conflicts Watch Program- CERES (Bolivia)

To a large extent, the relevance of the State as the core of social conflicts in Bolivia suggests, as we have alluded to already, a deeper explanation of the causes of social conflict: rent seeking or, more generally, appropriation of resources.

A combination of historical, political and sociological analysis showed that the role of the State in Bolivia has been crucial to have access to wealth, mostly natural resources ${ }^{16}$. Their abundance, from the Potosi silver mountain to the current gas reserves, was only available through political favors which, in a very unequal society, were instrumental in reproducing inequalities. Only the powerful could get political favors, particularly when institutions were weak and vulnerable. Therefore, no matter what the discourse was or still is, most social conflicts in Bolivia are disguised as political when in fact are just seeking to influence the distribution of existing

\footnotetext{
${ }^{16}$ See Laserna, Gordillo and Komadina (2006).
} 
wealth ${ }^{17}$. From influential lobbies to hunger strikes of policemen's wives, from peasants blockading roads to urban dwellers' demonstrations, from university students to civic committees requesting support for higher education or a development project, all have a common aspiration: to get a bigger share of a public budget that contains a big part of the contestable income. The Bolivian fiscal budget is supported by natural rents (or by international cooperation), and taxes, that would make easier to perceive the social costs of demands to the State, are paid only by a small fraction of the economic agents ${ }^{18}$.

A government, when confronted by social pressures, has basically three options: to avoid conflict by giving concessions, to repress conflict by the use of legitimate force, or to use all available resources to manage conflicts. Of course, it may combine them in different ways.

A careful analysis of the data shows that the only period when conflicts were mostly managed within the institutional boundaries of government was between 1985 and 1997. Processes of conflict avoidance prevailed in periods that lasted only as long as economic resources were available for the government to make concessions. Political resources have also restrictions, but often the removal of a cabinet or a president provides a new opportunity to define conflict management options. Repression has also been an option to tame conflicts in several occasions, but the use of force inevitably weakens the political legitimacy of governments when they are not utilized to create opportunities to experiment with other options. Something like this seems to have happened only once, in 1985, when a democratically elected government repressed social movements but immediately opened institutional channels for political conciliation. In other periods, repression lead to political weakening of governments, reaching political limits that determined sudden changes in government personnel, through military coups d'etat. It may be argued that those changes (cabinet crises and even Presidents being forced to quit) helped to avoid violence and therefore prevented a deeper and more dangerous weakening of the State as an institutional and normative framework for social, political and economic life.

The three different models of political management of social conflicts during the period, described above, can be seen in the next figure. Indicators on how conflicts were managed are the political regime (authoritarian or democratic) and the information on how many conflicts achieved what they demanded, which may be understood as the probability of success for social conflicts (see Figure 8, where the $\operatorname{Pr}(\mathrm{suc})$ variable represents the fraction of conflicts that are judged to have succeeded in their organizers' objectives).

The first model spans the period from 1970 to 1982, when low levels of conflict were attained by political repression but where the need for political legitimacy of the authoritarian rulers, since the period was dominated by the military, moved them to combine repression with concessions, raising the probability of success for social

\footnotetext{
${ }^{17}$ From this perspective it is not surprising to find a very high correlation between the number of conflicts and the publicly known natural gas reserves, which are indicators of rent expectations. Op. cit. pp.

${ }^{18}$ In fact, $0.3 \%$ of the tax payers provide with $56.2 \%$ of all collected taxes, and $77.2 \%$ pay $0.1 \%$ of all taxes. Moreover, there are only 508 thousand tax payers for an economically active population of around 4.5 million people. Data collected by CAINCO (2004).
} 
conflicts. The second model corresponds to the short period between 1982 and 1985 that may be recognized also after 1997 up to the present. It is a model of high levels of conflict that are in a way stimulated by an increasing probability of success since governments attempt to avoid conflict by making concessions. And the third model is the one located between 1985 and 1997 signaled by a declining number of conflicts and a declining probability of success during a democratic regime, which suggests that social demands were channeled through institutional means rather than conflicts.

Figure 8

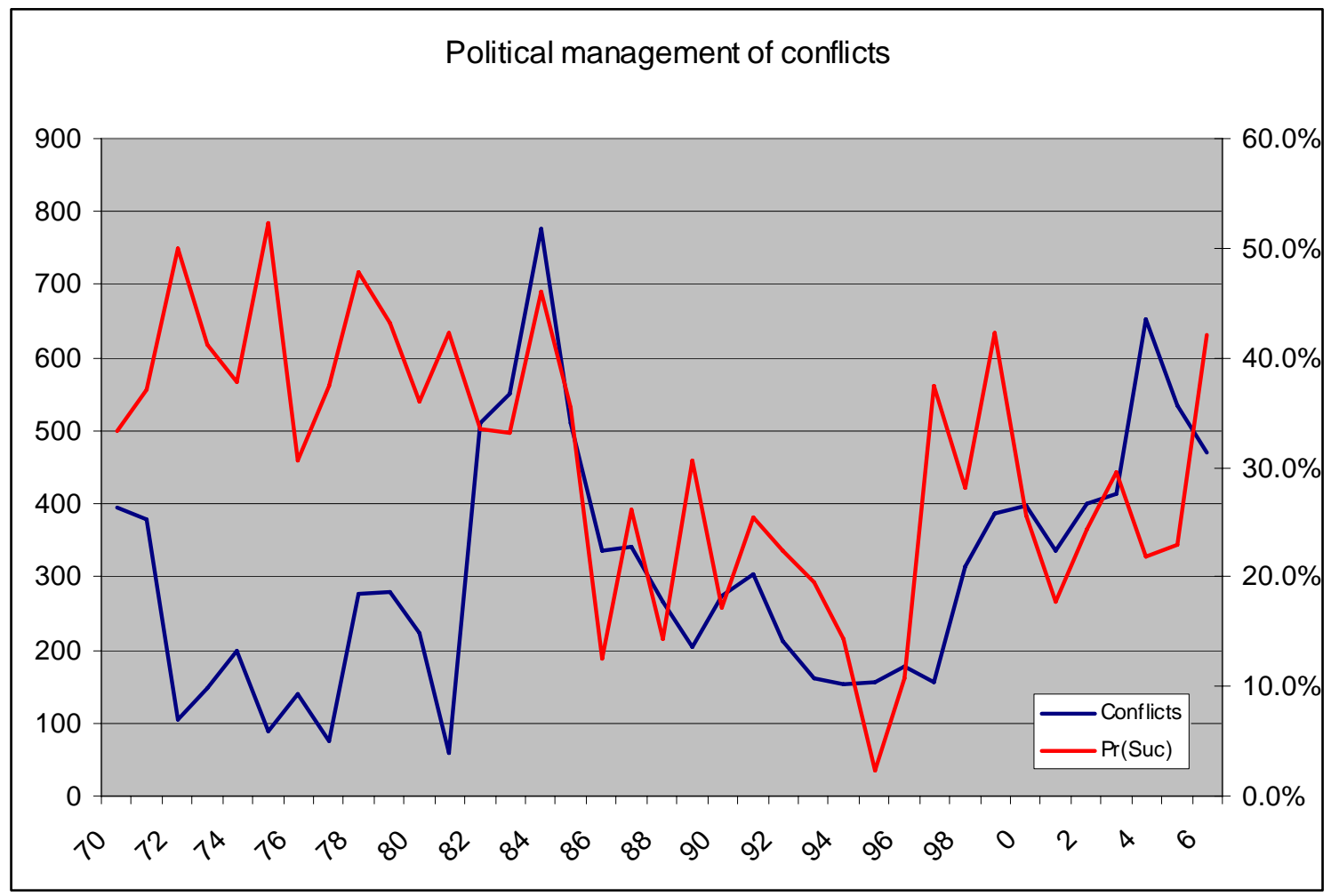

\section{Thinking about conflict as an economic activity and its effects on income and growth}

Protests, strikes, lobbying or demonstrations take time, effort, and money that become unavailable for useful production or consumption. Therefore, they may be regarded as appropriative activities - a term we will be using for much of the remainder of this paper. Note also that these activities are not combined cooperatively, as ordinary inputs in production are combined. Instead, they are combined adversarially: If one side expends more resources on influencing government policy, it increases the chance that a favorable policy to its side will be adopted and reduces the chance that their adversary will prevail. The more time a union spends organizing and mobilizing its members, advertising its position to the wider public, and building coalitions with other groups, the greater is its chance that it will win a strike and the lower is the chance of its employer. Whereas no strike needs to take place and bargains can be struck that would avoid such eventuality, nevertheless the union and the employers 
engage in appropriative activities so as to enhance their respective bargaining positions. In a world with perfect commitment, such activities would not be needed.

That is, appropriation takes away resources that could be used for useful production and thus tends to reduce production of all sides but not necessarily reported incomes since appropriation conflicts take place wherever there are "appropriable resources", that is, resources that are disputable or available for contestation. That happens not only when there are resources and they are concentrated but when their property rights or norms that regulate their use and access are not clear, so that the control or ownership of those resources are disputed. Therefore, incentives for appropriative conflict more than for investment or innovation are closely related with the level of security and, thus, impinge negatively on economic growth.

In this section we first present a simple model of appropriation to illustrate the basic ideas regarding the relationship between appropriation and income, and we also derive some hypotheses that we subsequently examine empirically. The model combines features from the static rent-seeking and conflict models in Tullock (1980) and Hirshleifer (1991) with those of dynamic models like those in Grossman and Kim (1996), Lee and Skaperdas (1998), and Gonzalez (2005). However, as indicated by our discussion at the end of the previous section, government policies in Bolivia varied over the period we examine in this paper. That is, the levels of appropriation depend on the degree of security and, more generally, the quality of governance. In Appendix B we examine a model in which the level of security and governance are endogenous and discuss some implications relevant to Bolivia at the end of this section.

\section{II.A A model of appropriation and its economic effects}

For analytical convenience, we consider two organized groups, $A$ and $B$, whereby each group has solved the collective action problem within them and behaves as a unitary actor. Income can be derived from two sources: One that is generated exogenously to the actions of each group and can be due to exports of natural resources or local spending by foreign NGOs, governments or international organizations. We denote the total income generated from these exogenous sources by $T$. This income is subject to contestation and capture by the two groups.

Furthermore, each group generates income $Y_{i}$ that at least partly depends on the actions of each group. We can call these actions investments and denote them by $I_{i}$, with $Y_{i}\left(I_{i}\right)$ being an increasing function of $I_{i}$. Part of this self-generated income is immune to contestation by the other side. Let $\sigma$ denote the share of $Y_{i}$ that is secure. The remainder of own-generated income, $(1-\sigma) Y_{i}$, is subject to contestation; that is, $(1-\sigma) Y_{A}+(1-\sigma) Y_{B}$ is in the same pool with $T$ and is contested by the two groups. The contested portion of income is divided between the two groups in proportion to their respective levels of appropriative activities. Let $a_{i}(i=A, B)$ denote the level of 
appropriative activity of $i=A, B$. Then, the share of contested income captured by group $i$ is: ${ }^{19}$

$$
p_{i}\left(a_{i}, a_{j}\right)=\frac{a_{i}}{a_{i}+a_{j}} \text { where } i \neq j \text {, for } a_{i}+a_{j}>0
$$

Then, the net incomes of the two groups are as follows:

$$
\begin{aligned}
& V_{A}=\frac{a_{A}}{a_{A}+a_{B}}\left[T+(1-\sigma) Y_{A}\left(I_{A}\right)+(1-\sigma) Y_{B}\left(I_{B}\right)\right]+\sigma Y_{A}\left(I_{A}\right)-a_{A}-I_{A} \\
& V_{B}=\frac{a_{B}}{a_{A}+a_{B}}\left[T+(1-\sigma) Y_{A}\left(I_{A}\right)+(1-\sigma) Y_{B}\left(I_{B}\right)\right]+\sigma Y_{B}\left(I_{B}\right)-a_{B}-I_{B}
\end{aligned}
$$

From the point of view of each group, there are two categories of income - the contested part that is captured through appropriation and the secure uncontested part and two sources of costs, the cost of appropriation and the cost of investing in the own, partly secure, income. We should emphasize, though, that from the social point of view investment is productive because it creates wealth, whereas as mentioned earlier appropriation does not lead to any increase in production as it is a purely redistributive activity of existing wealth.

We suppose that investments $I_{i}$ are undertaken first so that incomes $\dot{Y}_{i}$ are determined before levels of appropriation are chosen. ${ }^{20}$ For given level of $Y_{i}^{\prime} s$, it can be shown that the Nash equilibrium choice of appropriation are identical and equal:

$$
a^{*}=\frac{T+(1-\sigma) Y_{A}+(1-\sigma) Y_{B}}{4}
$$

Appropriation levels are increasing in exogenous income $T$, in endogenous group incomes $Y_{A}$ and $Y_{B}$, and in the degree of insecurity (or, conversely, the lower is the degree of security $\sigma$, the higher is the level of appropriation). ${ }^{21}$ This is because the higher the contested income is, the harder the parties involved will work to capture it. That is, one simple implication of this analysis is that, keeping the level of security constant, conflict and appropriation are positively related to income. Note that this is a statement about the short run. In the long run, higher levels of insecurity and conflict can be expected to reduce investment and, therefore, future income. At the same time, if growth were to be generated by increases in foreign aid or natural gas exports, the appropriation would increase just as it does in the static one-period case.

\footnotetext{
${ }^{19}$ This a function that was first used by Tullock (1980) and many other since then literatures as varied as those on rent-seeking, conflict, patent races, law and economics, tournaments, and even in sports economics. For properties of this and other functional forms, see Hirshleifer (1989).

${ }^{20}$ Different sequences of moves yield similar results. We have avoided the introduction of a truly dynamic model for simplicity, but the main ideas regarding the effect of appropriation on growth can be conveyed with the device of including investments in the static model here.

${ }^{21}$ We develop a model in which security itself is endogenous in the Appendix, and examine some of its implications in section IV.
} 
Subtracting this cost of appropriation, each group's net income as a function of own investment becomes:

$$
\begin{aligned}
& V_{A}\left(a^{*}\right)=\frac{\left.T+(1-\sigma) Y_{A}\left(I_{A}\right)+(1-\sigma) Y_{B}\left(I_{B}\right)\right]}{4}+\sigma Y_{A}\left(I_{A}\right)-I_{A} \\
& V_{B}\left(a^{*}\right)=\frac{\left.T+(1-\sigma) Y_{A}\left(I_{A}\right)+(1-\sigma) Y_{B}\left(I_{B}\right)\right]}{4}+\sigma Y_{B}\left(I_{B}\right)-I_{B}
\end{aligned}
$$

Supposing that returns to investment are diminishing, each group $i$ will choose its investment level, denoted $I_{i}^{*}$, so that

$$
\left(\frac{1-\sigma}{4}+\sigma\right) Y_{i}^{\prime}\left(I_{i}^{*}\right)=1
$$

Note that each group's optimal investment can be shown to be positively related to the security level $\sigma$. This is intuitively plausible, as the incentives to increase one's own income through investment should depend on how much of this income can be kept away from others. Since, by (1), conflict is negatively related to the same security level, we can conclude that conflict is negatively related to investment.

Over time, the growth path of Bolivia's income could be considered to have the two types of sources we have examined in this simple model: exogenous sources that may be due to terms of trade effects, discovery of new natural resources, or foreign aid (represented by $T$ in our model) and internal sources due to productive investment. To the extent that conflict is negatively related to investment, we should also expect conflict to be negatively related to investment-generated income growth. However, growth that is exogenously generated can either be not related to conflict (when that growth in unanticipated) or positively related to conflict (when that growth is anticipated).

Thus, from the simple model of conflict and appropriation (which is also consistent with much of the related literature that has examined more elaborate economic environments), we have derived the following implications:

- Conflict reduces the resources available for consumption and production.

- $\quad$ Conflict and (contestable) income are positively related

- $\quad$ Conflict and investment are negatively related

- $\quad$ Conflict and endogenously-generated growth are negatively related

- $\quad$ Conflict and exogenously-generated growth are either not related or positively related (the latter, when growth is anticipated).

\section{II.B On the role of governance}

In the model we just examined, the role of government, in terms of the variable $\sigma$, has been considered exogenous. However, as we have indicated towards the end of section I, the policies of Bolivian governments have varied since 1970, and to some extent these different policies could be considered as interacting with both the levels of economic performance and appropriation. Even when government has not been a direct participant, it should be considered a critical third-party with the potential to 
greatly influence the outcome of the other disputes in which it had not been directly involved.

In Appendix B we examine a model in which governance itself is endogenous, so as to provide guidance in thinking about the role of governance and its effect on conflict and economic performance. We show there that governance depends on economic variables like the value of contested resources. It is perhaps too obvious, yet important to recognize and emphasize the finding is that lower incomes could easily lead to lower expenditures on governance and, therefore, more conflict. Reductions in exogenous sources of income, like export revenue or foreign aid, for example, could precipitate a breakdown of either the public sector's capacity or the political process' ability to contain conflicts. However, it would be difficult to attribute changes in the level of security and governance solely on economic factors.

Knowledge of the particular historical development of Bolivia should be relevant and is likely to be significant. Another variable that is critical in the model of the Appendix is the degree of cooperation between the competing groups regarding how much they are willing to tax themselves and how to allocate public expenditures to the improvement of governance as well as how the groups are willing to use the normal political process.

\section{Conflict, Income, and Growth}

In this section we examine empirically some of the implications derived above. We use the data on conflict described in section I, and macroeconomic data that come from official sources (National Statistics Institute). We first provide rough estimates of the direct and spillover costs of conflict and then attempt to disentangle the correlations between conflict and the two different types of income growth we have laid out in the previous section.

\section{III.A Economic Costs of Conflict}

Different incidents of conflict have involved different numbers of participants and, therefore, different direct and indirect economic costs. In Figure 9 we report estimates on the direct costs of conflict (left scale), based on the time cost of the participants. [The method used to measure these costs is outlined in Appendix A]. The average over 35 years was a bit below US \$ 60 million per year (in 2004 prices), or roughly 1\% of GDP. As it is evident from Figure 9, our estimate of their direct costs follows closely the number of incidents of conflict, especially up to the mid1980s, which denotes that changes in the characteristics of conflict have also economic cost implications. 
Figure 9: Direct Costs of Conflict

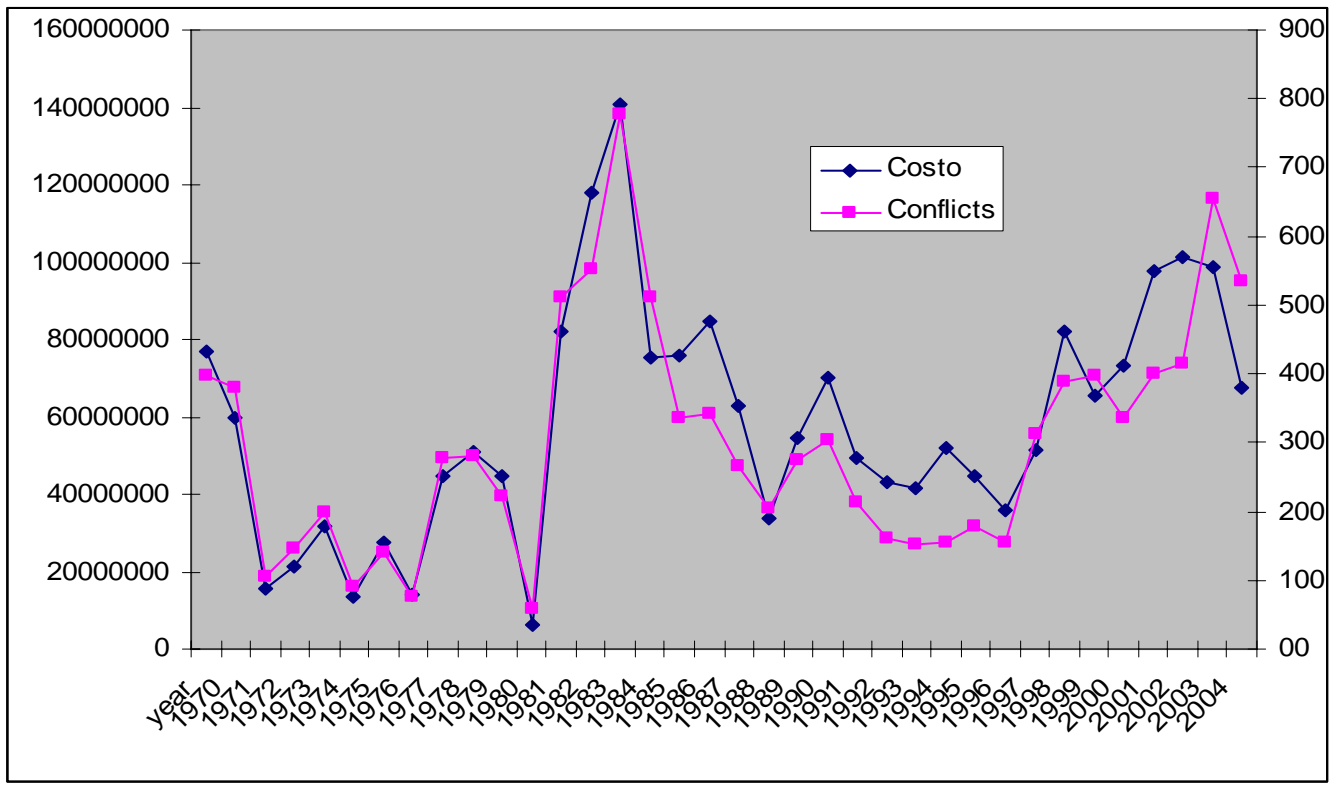

In fact, different incidents of conflict can also have widely different spillover costs. A strike in a manufacturing plant can affect the output of other downstream and upstream production and a road blockade can bring about wide-ranging disruption in the affected city or region, whereas a sit-in or a protest with few participants does not have much of an effect on economic activity. Based on assumptions of different "multipliers" regarding the spillover effects of different incidents, we have estimated the cost of spillovers and report it in Figure 10. [Again, for the method used, please see Appendix A.] The average yearly cost of spillovers was over US \$ 200 million per year (in 2004 prices), which represents more that 3\% of GDP. As can be seen in figure 8, these costs are much higher for the mid-1980s and the 2002-05 period.

Thus, the estimated direct and spillover costs significantly reduce GDP, with some years approaching a loss of as much as a tenth of GDP.

Figure 10: Spillover costs of conflict

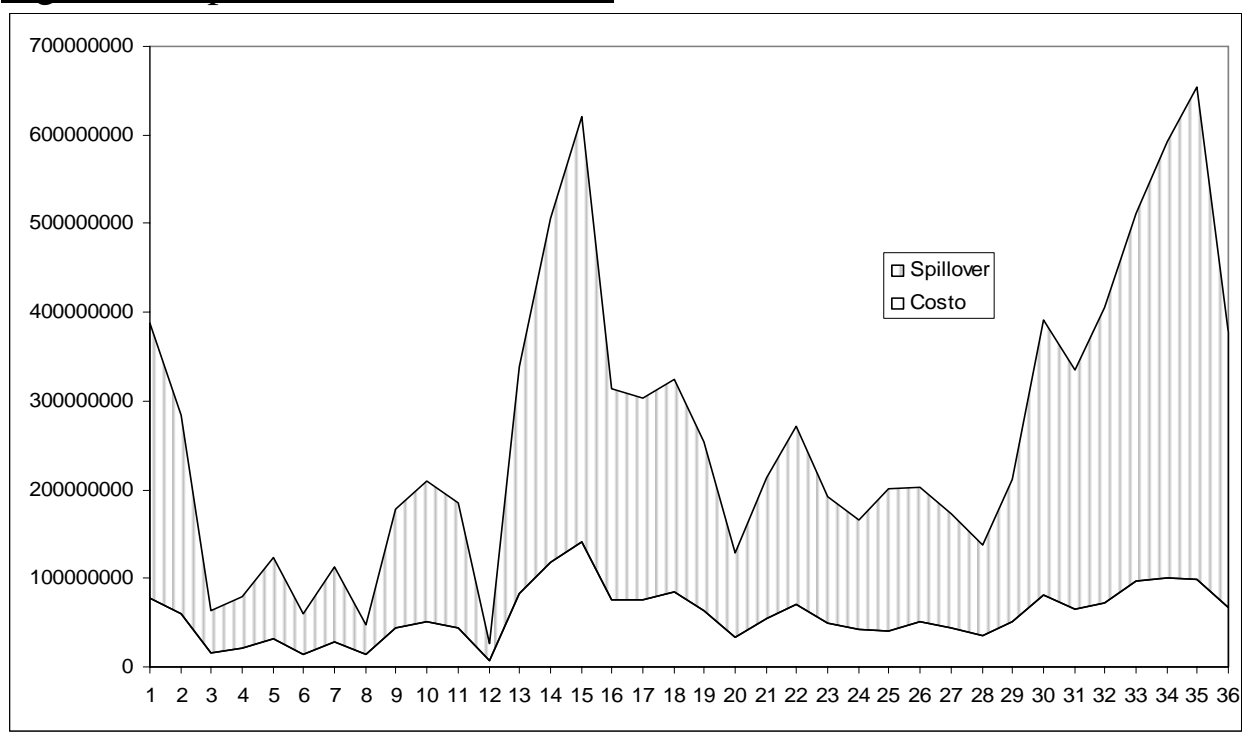




\section{III.B Overall Growth and Conflict}

Before trying to empirically distinguish between exogenous and endogenous source of growth, which is a rather difficult task, we first examine about any possible relationships between overall growth of GDP and conflict. The following figure plots GDP growth and conflict, with the correlation between the two variables appearing to be negative.

\section{Figure 11.}

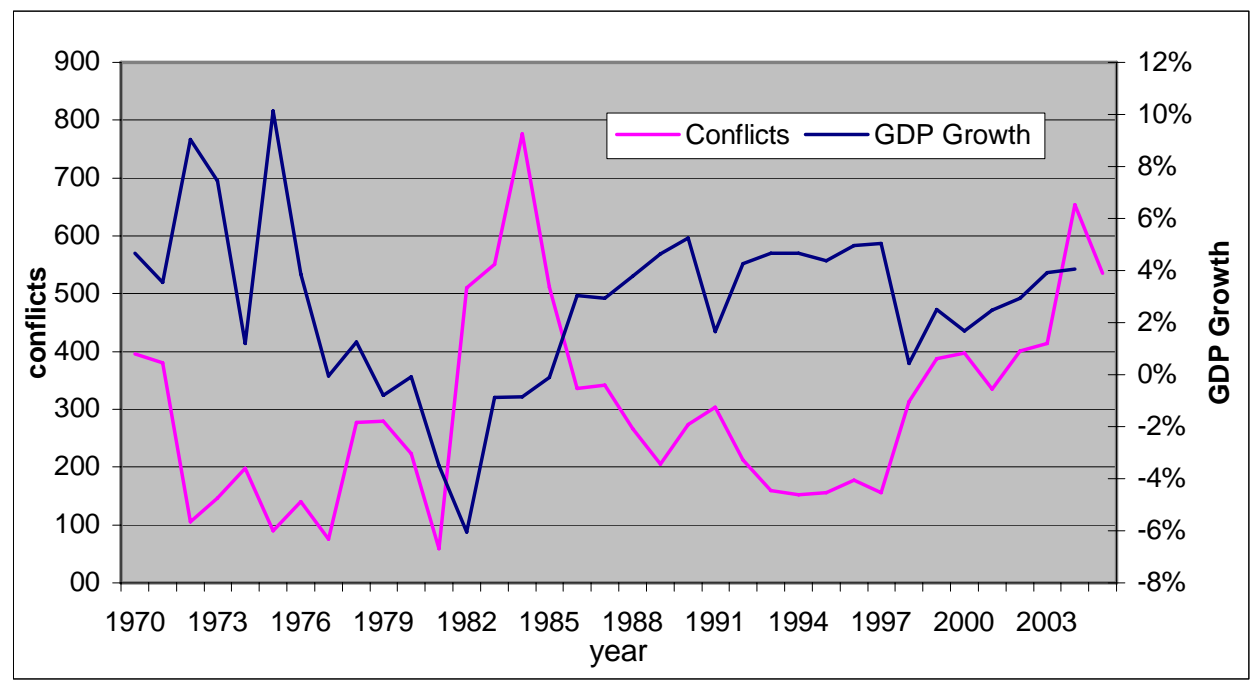

Source: Social Conflicts Watch Program- CERES (Bolivia) and INE.

Econometrically, at first there appears to be a negative a relationship between conflict and lagged values of GDP growth in Table 3. (We could not find a relationship between contemporaneous values of GDP growth and conflict). Adding a discrete variable of the degree of government repression (REP) however, reduces both the effect and the statistical significance of the growth variable. ${ }^{22}$

Table 3.

\begin{tabular}{|l|r|r|l|l|r|r|r|}
\hline $\begin{array}{l}\text { Dependent } \\
\text { Variable: } \\
\text { Conflicts }\end{array}$ & Constant & Trend & $\begin{array}{l}\text { GDP } \\
\text { Growth } \\
\text { lagged }\end{array}$ & REP & AR(1) & R2 & DW \\
\hline $\begin{array}{l}\text { (Std errors } \\
\text { in }\end{array}$ & 218 & 6.85 & -1723 & & 0.50 & 0.54 & 1.95 \\
parentheses) & $(105)$ & $(4.50)$ & $(812)$ & & $(0.17)$ & & \\
\hline & & & & & & & \\
& 32.81 & 0.39 & -758 & 132 & 0.54 & 0.71 & 2.06 \\
\hline
\end{tabular}

\footnotetext{
${ }^{22}$ The variable takes the value of 1 when the government has been considered predominantly repressive in dealing with conflict, the value of 2 if it has been moderately repressive and the value of 3 when the government has been judged to be reluctant to use force in dealing with conflict. For a justification of using such a variable, see our discussion in the last part of section I.
} 
We also regressed GDP growth on lagged values of conflict, with the results shown in the following table. Note that the addition of the REP variable in the regression changes neither the quantitative nor the statistical significance of the conflict variable on growth.

Table 4

\begin{tabular}{|l|r|r|r|r|r|r|r|}
\hline $\begin{array}{l}\text { Dependent } \\
\text { Variable: } \\
\text { GDP }\end{array}$ & Constant & Trend & $\begin{array}{l}\text { Conflicts } \\
\text { lagged }\end{array}$ & REP & AR(1) & R2 & DW \\
Growth & & & & & & & \\
\hline & 3262.5 & 89.4 & -0.805 & & 0.495 & 0.39 & 2.15 \\
& $(2268)$ & $(96.6)$ & $(0.380)$ & & $(0.168)$ & & \\
\hline & 5900 & 170 & -0.814 & -1900 & 0.332 & 0.48 & 2.15 \\
& $(2000)$ & $(80)$ & $(0.322)$ & $(900)$ & $(0.200)$ & & \\
\hline
\end{tabular}

The Granger causality test reported in Table 5 favors the hypothesis that conflict Granger-causes GDP growth. Given our hypotheses about the two opposite expected relationships between growth and conflict, it appears that the negative effect from conflict to lower (endogenously-generated) growth predominates. ${ }^{23}$ Since the overall growth rate contains both exogenous and endogenously-generated components, this is fairly strong, though indirect, evidence of the negative effect that conflict might have on economic growth.

Table 5

\begin{tabular}{lccc} 
Null Hypothesis: & Obs & F-Statistic & Probability \\
\hline \hline CONFLICTS does not Granger Cause & 33 & 3.211 & 0.0555 \\
GDPGRO & & \\
GDPGRO does not Granger Cause CONFLICTS & 2.532 & 0.0976 \\
\hline \hline
\end{tabular}

\section{III.C Conflict and Exogenously Generated Income}

We now turn to examining the possible effect of exogenous income growth on conflict, as hypothesized in section II. Since Bolivia is a small country, its terms of trade can be safely considered exogenous and changes in income that accompany changes in the terms of trade can be considered exogenous. We will examine the effect on conflict of two variables that can be considered exogenous: the terms of trade themselves and the "trade gain," a variable that measures changes in income due to changes in the terms of trade.

Figure 10 shows that the terms of trade, which generally depend on the price of Bolivia's primary exports, are positively correlated with the level of conflict.

\footnotetext{
${ }^{23}$ Strictly speaking, in the model of section II it is insecurity that causes both the levels of appropriative conflict and growth, rather than appropriative conflict directly causing growth.
} 
Figure 12. Social conflict and terms of trade. 1970-2005

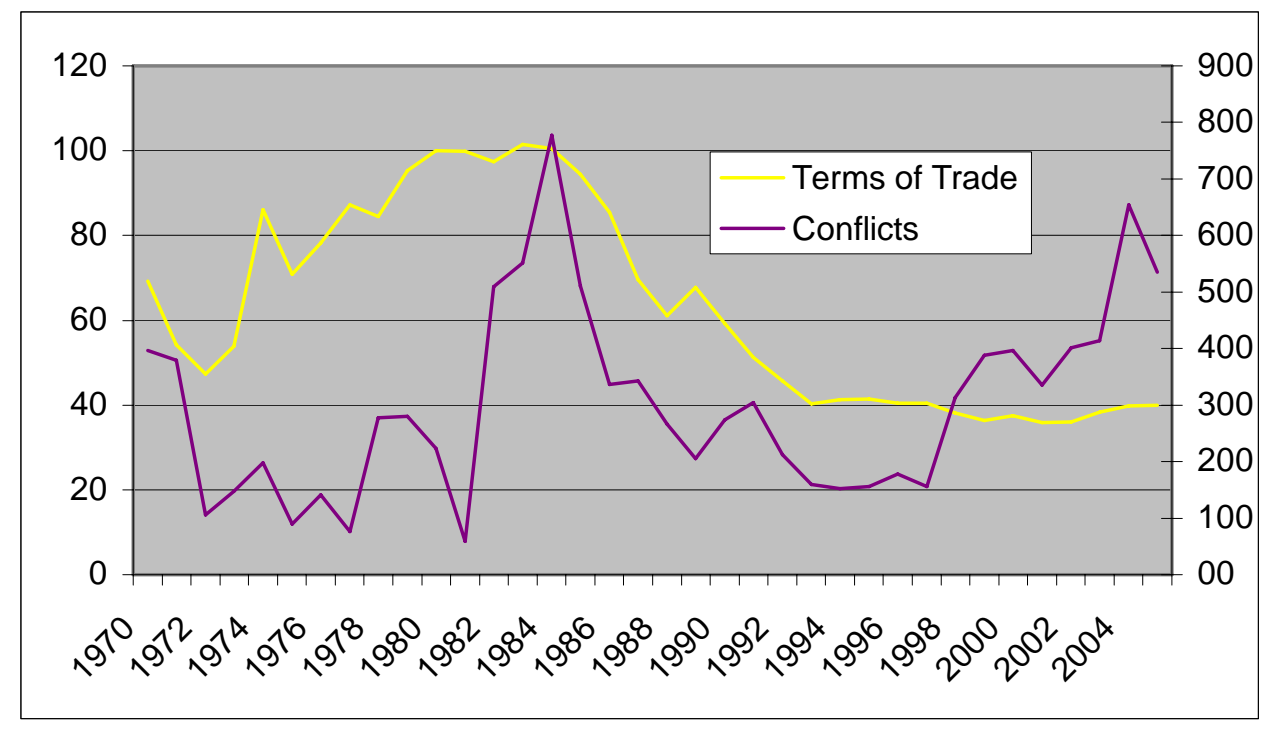

Source: Social Conflicts Watch Program- CERES (Bolivia) and INE.

The changes in income due to shifts in the terms of trade can be referred to as the "trade gain". The trade gain is calculated as the difference between the current trade balance deflated by a price index minus the trade balance calculated at the export and import prices of a reference year (base year):

$$
\mathrm{T}=((\mathrm{X}-\mathrm{M}) / \mathrm{P})-((\mathrm{X} / \mathrm{Px})-(\mathrm{M} / \mathrm{Pm}))
$$

Where $\mathrm{T}$ is the trade gain, $\mathrm{X}$ and $\mathrm{M}$ are exports and imports at current prices, $\mathrm{Px}$ and $\mathrm{Pm}$ are the price index for export and imports, respectively, and $\mathrm{P}$ is a price index.

The trade gain measures changes of purchasing power of the trade balance that are partly due to changes in the terms of trade. It must be remembered that the selection of variables refers to the specific Bolivian case, where exports are mainly composed of raw materials with little industrial value added, and where minerals and hydrocarbons provided relevant export revenues, not only for the country's economy but also, through fiscal rent capture, for public spending.

To calculate the trade gain we need to choose a base year and a price index (deflator). We calculated the trade gain with 1990 as base (taking the prices of exports and imports that prevailed in 1990 as the reference), and using the Consumer Price Index (IPC) as the deflator (measuring the purchasing power in terms of the consumer basket). One can interpret the trade gain as representing the "rents", if one considers that the base year reflects the situation without these "rents". Figure 11 shows the trade gain as percentage of the GDP. (For 1990 the trade gain is zero, because we chose this year as the base year). 
Figure 13. Trade Gain and social conflict. 1970-2005

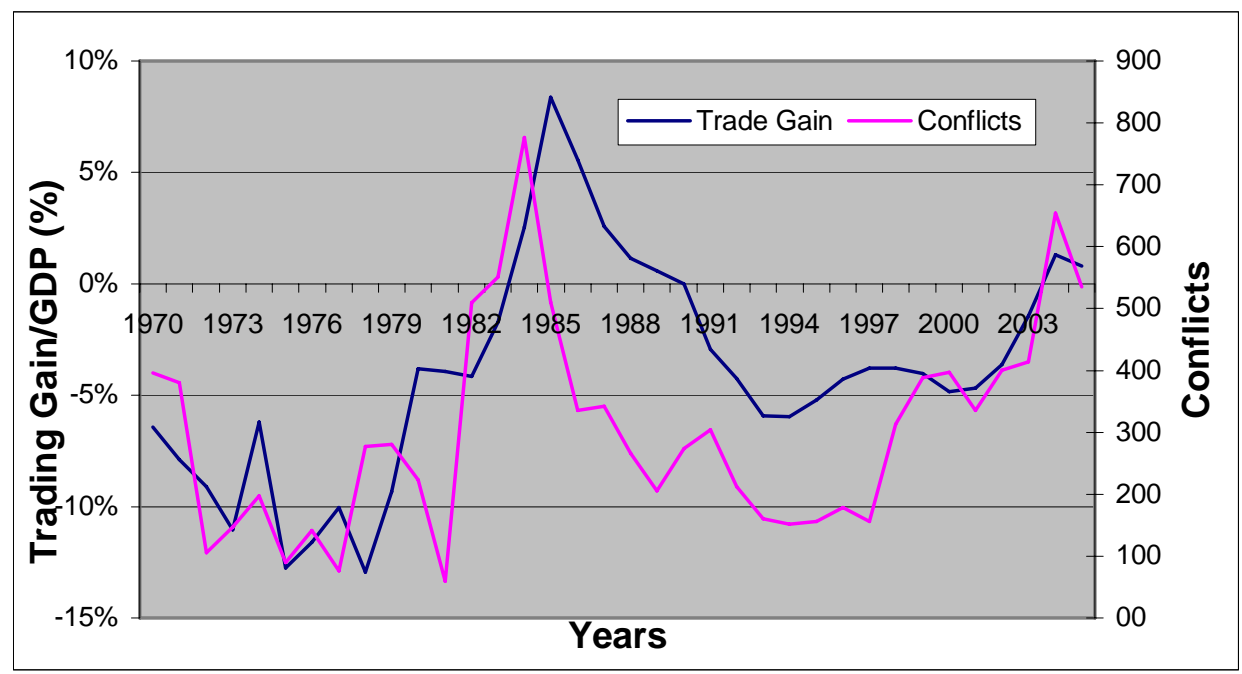

Source: Social Conflicts Watch Program- CERES (Bolivia) and INE

In Table 6 we regress conflict on our measures of exogenous income. In all cases, the sign is as hypothesized - increases in all our measures of income induce increases in conflict. In the case of no statistical significance - as is the case of the trade gain variable -- the addition of the REP variable improves it, in addition to increasing explanatory power.

Table 6.

\begin{tabular}{|c|c|c|c|c|c|c|c|c|c|}
\hline $\begin{array}{l}\text { Dependent } \\
\text { Variable: } \\
\text { Conflict }\end{array}$ & Constant & Trend & $\begin{array}{l}\text { Terms of } \\
\text { Trade }\end{array}$ & $\begin{array}{l}\text { Trade } \\
\text { Gain }\end{array}$ & $\begin{array}{l}\text { Trade } \\
\text { Gain } \\
\text { Lagged }\end{array}$ & REP & $\mathrm{AR}(1)$ & $\mathrm{R} 2$ & DW \\
\hline & $\begin{array}{l}-232.54 \\
(222.72)\end{array}$ & $\begin{array}{l}14.57 \\
(5.87) \\
\end{array}$ & \begin{tabular}{|l}
4.18 \\
$(2.07)$ \\
\end{tabular} & & & & $\begin{array}{l}0.53 \\
(0.15) \\
\end{array}$ & 0.51 & 2.07 \\
\hline & $\begin{array}{l}-191.27 \\
(189.29)\end{array}$ & $\begin{array}{l}4.96 \\
(5.50)\end{array}$ & $\begin{array}{l}2.62 \\
(1.82)\end{array}$ & & & $\begin{array}{l}110.72 \\
(34.17)\end{array}$ & $\begin{array}{l}0.50 \\
(0.17)\end{array}$ & 0.65 & 1.98 \\
\hline & $\begin{array}{l}263.11 \\
(114.22)\end{array}$ & $\begin{array}{l}4.93 \\
(4.42)\end{array}$ & & $\begin{array}{l}9.6 e-05 \\
(5.6 e- \\
0.5)\end{array}$ & & & $\begin{array}{l}0.48 \\
(0.18)\end{array}$ & 0.51 & 1.95 \\
\hline & $\begin{array}{l}125.7 \\
(53.7)\end{array}$ & $\begin{array}{l}-5.66 \\
(2.31)\end{array}$ & & $\begin{array}{l}0.00012 \\
(2.5 \mathrm{e}- \\
05)\end{array}$ & & $\begin{array}{l}169.75 \\
(27.2)\end{array}$ & $\begin{array}{l}0.13 \\
(0.175)\end{array}$ & 0.75 & 1.56 \\
\hline & $\begin{array}{l}-281.5 \\
(73.2)\end{array}$ & $\begin{array}{l}25.1 \\
(3.03)\end{array}$ & & & $\begin{array}{l}0.00018 \\
(3.1 \mathrm{e}- \\
05)\end{array}$ & & $\begin{array}{l}-0.076 \\
(0.204)\end{array}$ & 0.81 & 1.83 \\
\hline
\end{tabular}

\section{III.D Conflict and Investment}

In our discussion and model of the previous section, endogenously-generated growth and conflict are mediated through investment. That is, higher conflict tends to reduce 
investment which, in turn, tends to reduce that source of growth. The following graph shows the evolution of investment in the economy, measured through the gross fixed capital (as percentage of GDP), and social conflict.

Figure 14. Social conflict and investment. 1970-2005

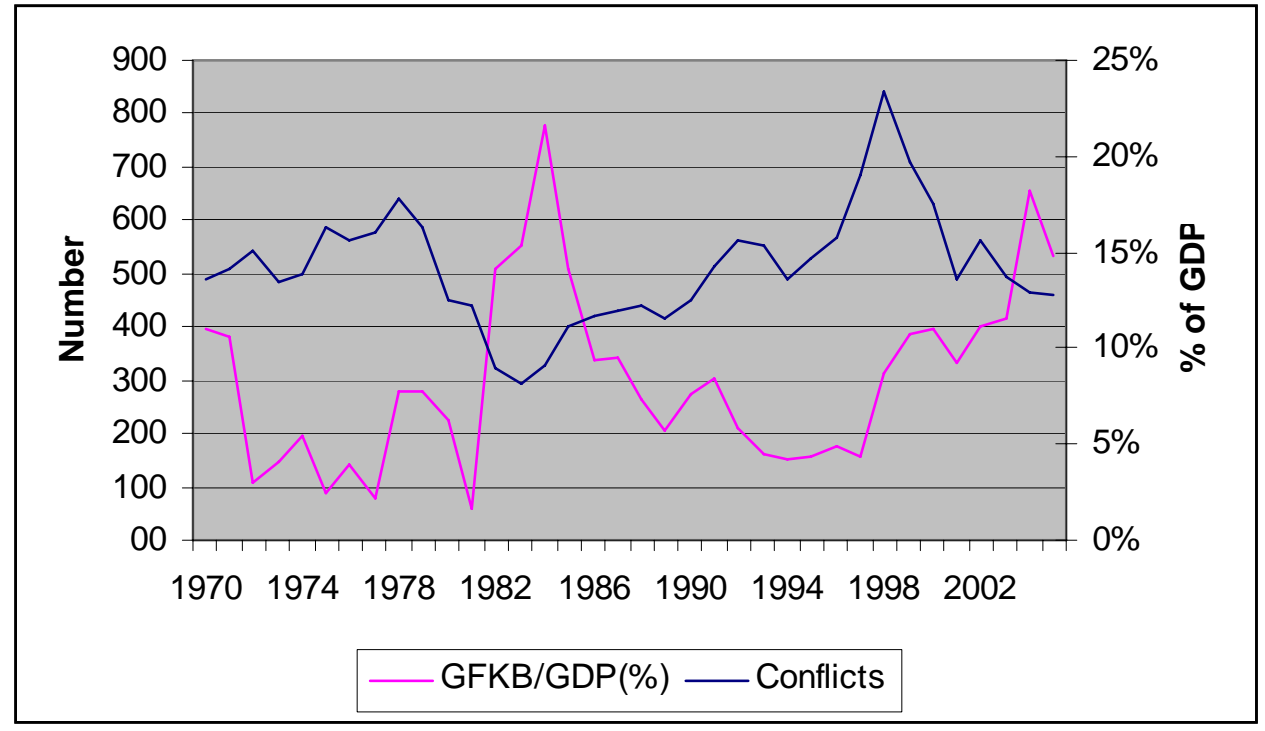

Source: Social Conflicts Watch Program- CERES (Bolivia) and INE

The relationship between investment and conflict appears to be negative for most of the period. We tried several specifications, including lagged values of investment, but the hypothesis of no correlation between investment and social conflict could not be rejected. The hypothesis of no cointegration could not be rejected either. It is possible that a large part of investment is not productive investment (in, say, plant and equipment) but housing and other investment that does not enhance future income, and is partly an outcome of increases in exogenously generated income.

The following graph shows the gross fixed capital building for the private and the public sector, as percentage of GDP for the period 1970-2002 (the statistical institute has not released data for later periods yet). Private capital building was depressed during the eighties, contemporaneous with the hyper-inflation, and expanded after the stabilization plan. In the late nineties, the effect of the capitalization program is clearly recognizable. The capitalization program, the Bolivian scheme of the Bolivian privatization, consisted on handling the control of public enterprises to private companies that made the highest investment offer for the company in a public auction. The company had to invest resources pledged to the company according to an investment plan, in theory doubling its value. In exchange of that the company received $51 \%$ of the enlarged company, while the rest of the shares went to a trust fund that benefited all Bolivians older that 21 years at the moment of the capitalization, with a yearly payment once they turned 65. As could be expected, this program stimulated private investment. But the process increased private investment much more than the investment pledged by the capitalization only.

\section{$\underline{\text { Figure } 15}$}




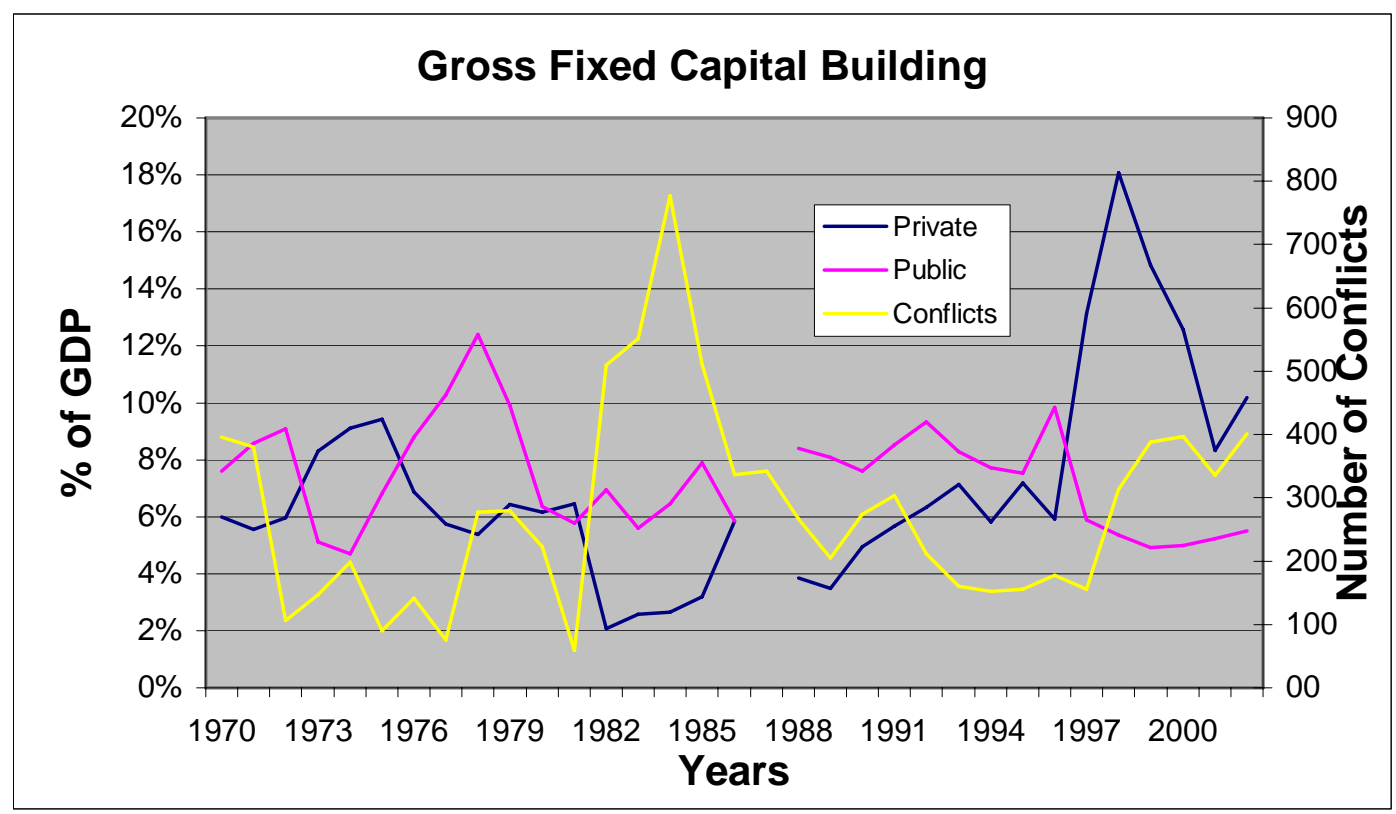

Since the bigger companies were acquired by the private sector, public investment decreased following the capitalization program. But not only the capitalization program increased private investment, it also generated an important reaction in some groups of the society. The privatization program was accompanied with significant public criticism and demonstrations against the process not just from the left but also from the more on the right ADN party.

To assess the relationship between private investment and conflicts we regressed private investment on conflicts, but only for the period 1970-1996. We did not consider the period 1997-2002 in the regression, because of the capitalization process. The results are shown in the following table.

Table 7

\begin{tabular}{|l|l|l|l|l|l|}
$\begin{array}{l}\text { Dependent } \\
\text { Variable }\end{array}$ & Constant & Conflicts & AR(1) & R2 & DW \\
\hline $\begin{array}{l}\text { Private } \\
\text { Investment }\end{array}$ & $\begin{array}{l}1125185 \\
(111114)\end{array}$ & $\begin{array}{l}-887 \\
(287)\end{array}$ & $\begin{array}{l}0.581 \\
(0.184)\end{array}$ & 0.68 & 1.93 \\
\hline
\end{tabular}

Conflict has a clear negative effect on private investment. As we hypothesized, more conflict had the effect of depressing private investment in the period studied.

\section{Concluding Remarks}

Social conflict has been an integral part of political and economic life in Bolivia. In certain periods, it became almost habitual, highly frequent and involving a wide variety of issues and groups. However, there have also been times of a more stable social environment, when the frequency of conflict declined and institutions had been working better. The strength of social organizations, whose tradition goes back to the beginning of the $20^{\text {th }}$ Century and became particularly relevant after the National Revolution of the 1950s, partially explain this central feature of Bolivian politics, 
which is enough to justify our analysis of the likely relationship between conflict and economic growth.

The direct and immediate spillover costs of conflict in Bolivia amount to at least several percentages of GDP, and in some years they have approached a tenth of GDP. Such costs are significant for any country, let alone for a low-income country like Bolivia. The actual impact may even be larger since the information on conflict comes from what the written media reports, which is much lower than the real figures. Other sources of appropriation and rent-seeking, not approximated by the data examined here, are also excluded in our estimates. Of course, the effects of conflict are not confined to just these costs, for conflict can affect the incentives for production, investment, and innovation, and, therefore, affect future growth.

In fact, growth seems to reduce conflict when endogenously generated, while it seems to cause conflict when exogenously generated. After specifying a simple model that generates hypothesis that take into account of these two different types of growth, we found evidence consistent with the hypotheses. In particular, variation in incomes due to changes in the terms of trade can be considered exogenous and we find that increases in such income induce greater conflict. On the other hand, greater conflict tends to reduce private investment, at least some of which could be considered to be a main source of future (endogenously-generated) growth. Finally, the degree of government repression tends, not surprisingly, to reduce conflict. ${ }^{24}$

A corollary of our approach is that a reduction in conflict would increase economic growth in Bolivia, provided that such a reduction is not diverted to some other (perhaps equally) costly appropriative activities. Taking the fight from the streets to the halls of parliament and ministries can be expected to reduce, though not eliminate, the costs of appropriation, provided that the distortions introduced through the normal political process are not much greater than those that have prevailed for the past four decades or so.

Building what has been variously described as "institutions," "governance”, or "property rights" is certainly very important even from a strictly economic point of view, but little is known about how it can be done in practice. However, both history and theory suggest that the main contending groups and their elites could in principle agree on greater cooperation, regardless of external conditions and economic influence, and dramatically improve the ways in which the economic pie is divided without dramatically changing the pie itself and the prospects for future growth. Again, though, little is known about how such an elite compact could be practically achieved.

\footnotetext{
${ }^{24}$ Of course, greater repression could well divert appropriation into other, less overt forms (for example, the distribution of rents among those who are close to the government).
} 


\section{Appendix A: Estimation of labor days lost and economic losses due to social conflicts.}

\section{Labor days.}

Based on observation and experience, we assigned an estimate of the mean number of participants in the events according to the social group and location registered in the data base. For example, for an event lead by traditional peasants in La Paz we assigned 10,000 participants, but only 5,000 in Cochabamba and 2,000 if the event took place elsewhere. If the event was lead by the cocaleros, we estimated only 2,000 if the movement took place in La Paz but 5,000 in Cochabamba. For events that took place at national level, bigger parameters were assigned.

Aggregating the data in 27 categories for social groups and 4 categories for location, the assigned parameters to estimate the number of individuals participating was:

1 Mining workers

2 Manufacturing workers

3 Construction workers

4 Other workers (SEMAPA, YPFB, FFCC)

5 Traditional peasants (highlands, valleys, lowlands)

6 Cocalero peasants and colonists

7 Urban dwellers and neighborhood committees

8 Housewives (marginal neighborhoods, workers wives)

9 Handicrafters and other non wage workers

10 Rural teachers

11 Urban teachers

12 Emplolyees of the financial system

13 Students (high sc hool-universities)

14 Proffessionals (including LAB pilots)

15 Public employees

16 University teachers and employees

17 Private sector employees

18 Petty traders

19 Truck drivers

20 Party militants

21 Citizens in general and civil committees

22 Unemployed / jobless / fired workers

23 Veterans -retired workers

24 Other groups

25 Bolivian Central Union of Workers COB

26 Central Unions at regional level

27 Indigenous, “originarios”

\section{La Paz}

5000

5000

8000

4000

10000

2000

10000

2000

5000

10000

15000

2000

20000

400

15000

1000

5000

10000

10000

4000

50000

1000

2000

CBB SC

1000

4000

Rest

5000

1000

4000

2000

5000

5000

7000

1000

5000

7000

10000

1000

15000

200

10000

500

4000

6000

10000

2000

50000

500

1000

2000

500

2000

500

4000

500

2000

4000

5000

500

5000

100

200

1000

2000

5000

500

20000

100

500

120000

1600

3500

50000

20000

20000

10000 
Since august 1985 the data base registers how many days each event lasted so we estimated the number of lost days by multipliying the estimated number of participants using the parameters of the previous table times the duration. Missing data was assigned just one day.

For the period before 1985, we assigned the average number of days that the events with information lasted (2.2 days).

\section{Economic losses.}

From the 2004 Household Survey we obtained the average monthly income obtained from labor by occupation and estimated a daily rate in US dollars for each social group category. They ranged from 2.3 dollars per day in the case of small peasants to 9.6 dollars per day in the case of public servants and private employees.

Multipliying the lost labor days times the daily income rate, we have the estimated economic losses of each event.

By using means comparisons by year, it was possible to obtain the total number of days lost in conflict and an estimation of their economic significance expressed in 2004 US dollars.

Economic losses should also take into account the spillover effects of social conflicts. When a group of mining workers blocks a road, not only their labor days are lost but the blockade also has an impact on the productive day of other people. We estimated these costs using the following criteria.

For each type of event we assigned a multiplier effect, so that the total cost of an event would be the previous estimation multiplied by the multiplier effect. Some types of events are much more costly for the society than others, and the predominance of certain events over other types may signal levels of disruption that are not necessarily reflected in the number of conflicts.

\begin{tabular}{|c|c|c|c|}
\hline Code & Type of event & $\begin{array}{l}\text { Multip. } \\
\text { Effect }\end{array}$ & Criteria \\
\hline 1 & Cívic stoppage & 2 & $\begin{array}{l}\text { What happens in one region partially affects the } \\
\text { neighboring regions. }\end{array}$ \\
\hline 2 & $\begin{array}{l}\text { Strike for a } \\
\text { defined period }\end{array}$ & 2.77 & $\begin{array}{l}\text { To stop working affects the company, its providers and its } \\
\text { suppliers. We assign a multiplier that is the reverse of the }\end{array}$ \\
\hline 3 & $\begin{array}{l}\text { Strike for } \\
\text { undefined } \\
\text { period }\end{array}$ & 2.77 & $\begin{array}{l}\text { labor cost of the industry. The labor cost in Bolivia is } \\
\text { estimated at a similar percentage of the household } \\
\text { consumption over the total demand (36\%), so that the }\end{array}$ \\
\hline 4 & Hunger strike & 2.77 & multiplier effect is $100 / 36=2.77$ \\
\hline 5 & Urban blockade & 12.5 & $\begin{array}{l}\text { Due to the population density in cities, we estimate that } \\
\text { every individual participating in an urban blockade affects } \\
100 \text { more individuals, but not for the same amount of time } \\
\text { of the blockade, since people have other options to move } \\
\text { around. So we assigned one hour loss per individual } \\
\text { suffering a blockade in the city. This is } 1 / 8 \text { of a labor day, } \\
\text { so that the final effect is } 100 \star 1 / 8=12.5\end{array}$ \\
\hline 6 & Rural blockade & 10 & $\begin{array}{l}\text { Rural blockades affect less people but for more time, } \\
\text { since they do not have much more options to drive around } \\
\text { and avoid the blockade. In our case we estimated that for } \\
\text { every person blocking a road, } 20 \text { people are affected for at } \\
\text { least } 4 \text { hours or half a labor day. So the final effect is }\end{array}$ \\
\hline
\end{tabular}



7 Marchings and walks
$20 * 4 / 8=10$
3.12 Marchings and walks on streets and avenues have a similar effect as urban blockades but they last less, so we estimated its impact to be one fourth of the urban blockade: 3.12 (no difference between urban and rural)
8 Take obres
9 Strike on site
10 Emergency
11 Other
Take obres usually involve those participants in the action and those individuals affected by the take over of an institution or a company. So that we estimate its multiplier effect to be twice as the labor strike.
2.77 The impact is similar to that of a strike but, of course, with more publicity since workers remain in the building or the company's place.
It does not affect more people.
4.737 Since these category involves a variety of events, we assign to it the average of the rest.

These parameters were used to estimate the spillover effect, by multipliying them to the estimated number of days lost or the economic cost of the conflicts.

\section{Appendix B: Modeling Conflict and Governance as economic activities}

In this Appendix, we relax the assumption of perfect and costless enforcement of property rights in a variation of the model of section II. Though simple, the model allows for the endogenous costly determination of governance, conflict, and income, all as functions of economic endowments and the valuation of such endowments in international markets. We show that governance depends on economic variables like the value of contested resources. However, governance also can critically depend on norms of cooperation as well as on historical contingencies. Thus, it would be difficult to attribute changes in the level of security and governance solely on economic factors. Knowledge of the particular historical development of Bolivia should be relevant and is likely to be significant.

We continue to consider two organized groups, $A$ and $B$, each as a unitary actor. Again, income can be derived from two different types of endowments: One that is contestable and exogenous and another is endogenously generated. Let each group initially posses $T$ units of the contestable endowment and have $Y$ units of the secure endowment. Then, in the absence of any conflict or governance costs, the gross value of each group's endowment is:

$$
R=T+Y
$$

The parts of the government's budget that consist of transfers to each group and which can be fought over in the future can be considered part of this category of income. That is, to keep our analysis simple, we include in $T$ all the economic resources, including those of the government's budget, that the two groups can be expected to fight over.

The nature and costliness of fighting over the contestable part of each group's income will be examined in detail next. Broadly, the two groups make the following two sets of decisions: 
1. The level of government protection of each group's contestable income is determined by past and current taxation and other decisions.

2. Taken the level of protection as given, each group engages in appropriative activities that determine each group's final allocation and income.

That is, we consider a setting in which both governance and conflict are costly economic activities. We begin with the analysis of the second stage of appropriation and conflict.

\section{Conflict}

We model insecurity in a somewhat more sophisticated way than we did in section II. Each group could engage in appropriative activities in order to defend its own contestable income, $T$, or to challenge that of its adversary. Let $a_{i j}$ denote the level of appropriation that group $i$ engages in relation to the contestable income of group $j$. Note that if $j=i$, then this is the level of appropriative activity in defending own income and if $j \neq i$, then this is the challenging level of appropriation against $i$ 's adversary.

Appropriative activities determine the probability of winning or, equivalently, the share of each contested income ${ }^{25}$ in the following fashion:

$$
\begin{gathered}
p_{i i}\left(a_{i i}, a_{i j}\right)=\frac{\phi a_{i i}^{m}}{\phi a_{i i}^{m}+(1-\phi) a_{i j}^{m}}(m \in(0,1]) \\
p_{i j}\left(a_{i i} a_{i j}\right)=\frac{(1-\phi) a_{i j}^{m}}{\phi a_{i i}^{m}+(1-\phi) a_{i j}^{m}} i \neq j \text { and } \phi \in\left[\frac{1}{2}, 1\right]
\end{gathered}
$$

$p_{i i}\left(a_{i i} a_{i j}\right)$ is the share of its contested income the defending group $i$ keeps and $p_{i j}\left(a_{i i}, a_{i j}\right)$ is the attacker's share of the defender's contested income. Such functions, commonly called contest success functions, have been used in many different areas of economics, including in rent-seeking, political campaigning, lobbying as well as in the economics of conflict. In its defense/offense interpretation, this functional form has been used extensively by Herschel Grossman (e.g, Grossman, 2001).

The critical parameter that determines the security of property rights is $\phi$. The closer to 1 is $\phi$, the more secure the property rights of the defender are, whereas the closer the value of that parameter is to $1 / 2$, the more insecure property rights are with the limiting case of $\phi=1 / 2$ being one in which there is no advantage to being a defender relative to the challenger. For our purposes here, we can broadly think of $\phi$ as being determined by the strength of the courts, the state agencies and bureaucracies, and the political apparatus of the country as a whole. How easy is it for the holder of the (uncertain) property right to argue against the challenger in front of a court, bureaucrats, politicians, or the public at large so as to convince such audiences that

\footnotetext{
${ }^{25}$ Probabilities of winning and shares are equivalent under risk neutrality and divisibilty of incomes. For exposition purposes, we will employ the share interpretation in the remainder of this paper.
} 
the defender is right and not the challenger? The closer $\phi$ is to 1 , the easier it is for the defender and the more difficult it is for the challenger to do so. Also, the more professional are the courts and the bureaucracy, and the greater are the checks and balances in politics, the closer would $\phi$ be to 1 .

Another parameter of interest is $m$. It can be thought of as a measure of the ease or effectiveness of producing appropriative effort. ${ }^{26}$ Working directly through the political process and the state (the courts, the bureaucracy, or the halls of parliament) would entail a lower $m$ to fighting it out in the streets or even in the court of public opinion.

In this subsection we take $\phi$ as well as $m$ as given. Given the level of security, the payoff functions of the two groups are the following:

$$
\begin{gathered}
V_{A}^{c}(a)=\frac{\phi a_{A A}^{m}}{\phi a_{A A}^{m}+(1-\phi) a_{A B}^{m}} T+\frac{(1-\phi) a_{B A}^{m}}{\phi a_{B B}^{m}+(1-\phi) a_{B A}^{m}} T+Y-a_{A A}-a_{B A} \\
V_{B}^{c}(a)=\frac{(1-\phi) a_{A B}^{m}}{\phi a_{A A}^{m}+(1-\phi) a_{A B}^{m}} T+\frac{\phi a_{B B}^{m}}{\phi a_{B B}^{m}+(1-\phi) a_{B A}^{m}} T+Y-a_{A B}-a_{B B}
\end{gathered}
$$

where $a=\left(a_{A A}, a_{B A}, a_{B B}, a_{A B}\right)$ are the strategies of the two groups, one each for defense of own endowment and challenge of the other group's endowment.

Given the sharing functions and the identical endowments that the two groups have, it can be shown that the (Nash) equilibrium levels of appropriation are identical for defense and challenge and across the two groups: ${ }^{27}$

$$
a_{A A}^{*}=a_{B A}^{*}=a_{B B}^{*}=a_{A B}^{*}=\phi(1-\phi) m T
$$

Note that the closer $\phi$ is to 1 (that is, the better governance is), the lower is the level of appropriation. ( $\phi(1-\phi)$ is minimized at 1 reaches its maximum at $\frac{1}{2}$.) Each group keeps a $\phi$ fraction of its own contested endowment and receives a $1-\phi$ fraction of its adversary's contested endowment. Given the level of security, the equilibrium payoff of each group equals:

$$
\begin{aligned}
V_{i}^{c} \equiv V_{i}^{c}\left(a^{*}\right) & =\phi p T+(1-\phi) T+R-2 \phi(1-\phi) m T \\
& =[1-2 \phi(1-\phi) m] T+R \\
=\sigma T & +R \text { where } \sigma \equiv 1-2 \phi(1-\phi) m
\end{aligned}
$$

\footnotetext{
${ }^{26}$ Note that $m$ is the elasticity of the "impact" function $a^{m}$; that is, $m=\frac{\partial a^{m}}{\partial a} / \frac{a^{m}}{a}$. Also, Jia (2005) provides a stochastic derivation of contest success function, where the output of each side's effort is stochastic, with $m$ being a parameter that reduces the variability of output as a function of effort (with higher $m$ reducing that variability).

${ }^{27}$ If endowments for the two groups were different, the levels of appropriation would be higher for the endowment that is higher but the levels of the defense and challenge would still be identical.
} 
As can be expected the lower is the level of protection $\phi$, the lower is the equilibium payoff of each group. Note how, with security given, changes in the value of the endowment $T$ (for example, by the discovery of new tradeable resources, the exhaustion of old ones, or the change in the international price of existing resources) lead to monotonic changes in appropriation and in equilibrium payoffs. In particular, for fixed levels of security, a reduction in $T$ reduced appropriation and increases equilibrium payoff. We next examine how security can be determined by current and past conditions in stage 1 of the two-stage process we have outlined above.

\section{Endogenous Governance}

The level of $\phi$ (as well as of $m$ ) and, therefore, the fraction $\sigma$ of the contestable endowment that each group eventually keeps would in general depend on the societal and political norms, but more importantly for the case of modern, anonymous property rights on the country's political development and the fiscal choices and organizational decisions that have been made in the past as well as those made in the present. Many of these choices can be expected to depend on the country's characteristics and, as a first approximation, its current conditions can be considered both similar to those in the past and, to the extent that the conditions might have changed, current conditions can be expected to have considerable influence on current governance. In particular, the resources available for paying and training judges, civil servants, or the police can have an immediate impact on the quality of governance and property rights. These resources are largely determined by the taxing ability of the state, which could in turn greatly depend on the ability of the two contending groups to agree on taxation. Past decisions on taxation also have impact on the quality of governance though the educational level of not just government employees but also of others in the country (lawyers, politicians, engineers, citizens in general) and through other collective-good investments from court buildings to university budgets.

Thus, we consider the level of security to be a function of past and present investments on governance so that:

$$
\sigma=\sigma\left(g_{o}+g_{A}+g_{B}\right)
$$

where $g_{o}$ denotes the inherited investments in governance and $g_{A}$ and $g_{B}$ are the current contributions to governance by the two groups. We suppose security is strictly increasing in its argument $\left(\sigma^{\prime}>0\right)$ at a decreasing rate $\left(\sigma^{\prime \prime}<0\right)$.

How the level of governance expenditures - which we suppose to equal total taxes is determined is of course an important issue. Security here is a public good and in the provision of public goods through taxation, there are two focal regimes: One in which public good provision maximizes total welfare and the other in which its provision is non-cooperative and generally inefficient. We shall examine both types of provision regimes and discuss their implications and their relation to Bolivia.

The welfare-maximizing choice of governance expenditures solves the following problem:

$$
\begin{gathered}
\max _{g_{A}+g_{B}} V_{A}^{c}+V_{B}^{c}-g_{A}-g_{B} \\
=2 \sigma\left(g_{o}+g_{A}+g_{B}\right) T+2 Y-g_{A}-g_{B}
\end{gathered}
$$


Under the condition that the optimum is interior, or that the inherited level of governance is not too high and there are no liquidity constraints, ${ }^{28}$ the welfaremaximizing level of governance expenditures satisfies the following first-ordercondition:

$$
2 \sigma^{\prime}\left(g_{o}+\hat{g}_{A}+\hat{g}_{B}\right) T-1=0
$$

It is clear that total optimal expenditure $\hat{g}_{A}+\hat{g}_{B}$ can be distributed in many different ways between the two groups (and that in itself can be a source of contention that makes optimal provision difficult to implement). It is clear that $\hat{g}_{A}+\hat{g}_{B}$ is positively related to the value of the contested resource $T$ and inversely related to the inherited investments in governance $g_{o}$.

The non-cooperative contributions to governance are determined as the Nash equilibirum of the game with the following payoff functions:

$$
\begin{aligned}
& V_{A}\left(g_{A}, g_{B}\right)=\sigma\left(g_{o}+g_{A}+g_{B}\right) T+Y-g_{A} \\
& V_{B}\left(g_{A}, g_{B}\right)=\sigma\left(g_{o}+g_{A}+g_{B}\right) T+Y-g_{B}
\end{aligned}
$$

It is straightforward to show that the equilibrium is characterized by the same condition for both groups (and also results in determining only the total and not the particular distribution of expenditures between the two groups):

$$
\sigma^{\prime}\left(g_{o}+g_{A}^{*}+g_{B}^{*}\right) T-1=0
$$

As in the case of optimal expenditures, Nash equilibrium expenditures are positively related to $T$ and inversely related to inherited investments in governance $g_{o}$. By comparing (A1) to (A2) and given the strict concavity of $\sigma(\cdot)$, expenditures in governance under the Nash equilibrium are lower than optimal expenditures $\left(g_{A}^{*}+g_{B}^{*}<\hat{g}_{A}+\hat{g}_{B}\right)$, for, under Nash equilibrium, each group only cares about its own welfare and no weight is put on the adversary's payoff.

We are particularly interested on the effect of a reduction in the terms of trade (a reduction in $T$ ) on the levels of security and appropriation. The reason is that volatility and significant reductions in the price of Bolivia's major exports - from silver early in its history to tin during the 1980s - could have been important for government stability, security of property rights, and the level of socio-political conflict, with all affecting directly and indirectly economic performance. That is, the external shock of a price reduction in exportable could have had effects on income that go far beyond the direct effect of the price reduction itself.

Considering the case of the non-cooperative provision of security, where $\sigma^{*} \equiv \sigma\left(g_{o}+g_{A}^{*}+g_{B}^{*}\right)$, and noting from (5) that $\alpha_{i i}^{*}=\phi(1-\phi) m T=\frac{1-\sigma^{*}}{2} T$, the overall effect of the value of the contestable endowment on equilibrium appropriation can be shown to be the following:

\footnotetext{
${ }^{28}$ In practice, especially for low-income countries like Bolivia, we can expect the liquidity constraints to be more likely to be binding, especially for the case of welfare-maximizing provision.
} 


$$
\frac{\partial a_{i i}^{*}}{\partial T}=\frac{\left(\sigma^{*^{\prime}}\right)^{2}}{2 \sigma^{* \prime}}+\frac{1-\sigma^{*}}{2}
$$

The first term is negative since $\sigma^{\prime \prime}<0$, whereas the second term is positive. The first term is negative because it reflects the effect on appropriation via governance - a reduction in $T$ reduces governance and security and increases appropriation (that is, $\phi(1-\phi) m$ increases as a result of a reduction in governance expenditures). The second effect is positive because it is the direct effect on appropriation. Overall, the effect of the value of $T$ on equilibrium appropriation is ambiguous. If the governance effect (first term of (A3)) dominates the total effect is negative; if the direct, value-ofprize effect dominates the total effect is positive.

$$
\frac{\left(\sigma^{*^{\prime}}\right)^{2}}{\sigma^{* \prime \prime}}+1-\sigma^{*}<0
$$

or when

$$
-\frac{\sigma^{* \prime \prime}}{\sigma^{*^{\prime}}}>\frac{\sigma^{*^{\prime}}}{1-\sigma^{*}}
$$

which occurs when $-\frac{\sigma^{* \prime \prime}}{\sigma^{* \prime}}$ is large enough, or, when $\sigma$ is sufficiently concave.

Regardless of whether the two groups choose the optimal or non-cooperative levels of governance, the qualitative effects on security and appropriation are similar. Of course, when the choices are non-cooperative the negative effects of a reduction in $T$ are higher on levels of security, on appropriation, and on real income.

However, the level of $T$ might also have an independent effect on the choice of governance expenditures themselves. If, for example, the two groups were to originally have the norm of choosing the optimal level of governance but suddenly face a shortfall in their expected incomes, they might refrain from that optimal level of governance expenditures and decide on a lower level or even the non-cooperative level of governance expenditures. Such a choice might come about because of internal disputes within groups as well as between the groups that are often precipitated by reductions in incomes or other crises. Allowing for a continuous effect of $T$ on the level of cooperation between the groups regarding governance expenditures, we can posit that these expenditures are a convex combination of the optimal and noncooperative choices:

$$
g_{i}^{\gamma}=\gamma(T) \hat{g}_{i}+(1-\gamma(T)) g_{i}^{*} \text { where } \gamma^{\prime}(\cdot)>0 \text { and } i=A, B
$$

Then, the total effect on appropriation of changes in $p T$ becomes:

$$
\frac{\partial a_{i i}^{*}}{\partial T}=-\frac{\gamma^{\prime}(T) \sigma^{\gamma^{\prime}}\left(\hat{g}-g^{*}\right)}{2}+\frac{\sigma^{\gamma^{\prime}}}{2}\left[\gamma \frac{\hat{\sigma}^{\prime}}{\hat{\sigma}^{\prime \prime}}+(1-\gamma) \frac{\sigma^{*^{\prime}}}{\sigma^{*^{\prime \prime}}}\right]+\frac{1-\sigma^{\gamma}}{2}
$$

where $\sigma^{\gamma} \equiv \sigma\left(g_{o}+g_{A}^{\gamma}+g_{B}^{\gamma}\right), \hat{g} \equiv \hat{g}_{A}+\hat{g}_{B}, g^{*} \equiv g_{A}^{*}+g_{B}^{*}$, and $\hat{\sigma} \equiv \sigma\left(g_{o}+\hat{g}_{A}+\hat{g}_{B}\right)$.

The last two terms of (A5) are qualitatively similar to those of the two terms in (A3). The first term in (A5) is new and is due to the change in the level of governance 
choices induced by a change in $T$; that effect is negative since $\gamma^{\prime}(T)>0, \sigma^{\gamma^{\prime}}>0$, and $\hat{g}>g^{*}$. Recapitulating, a reduction in the value of the contested resource $T$ has three effects:

(i) A tendency to reduce appropriation because the value of the contestable resource is reduced (represented by third term in (A5);

(ii) A tendency to increase appropriation because it reduces the governance expenditures and security (represented by second term in (A5));

(iii) A tendency to increase appropriation because it reduces the degree of cooperation on the choice of governance expenditures between the groups (represented by the first term in (A5)).

Of course, the opposite effects are present on the real final income of the groups. In addition, each group's income is reduced directly since $T$ is part of income, but which is counterbalanced by the reduction in governance expenditures as a result of a reduction in $T$. Final real income for each group is:

$$
Y_{i}^{r}=\sigma\left(g^{\gamma}(T)\right) T+R-g_{i}^{\gamma}(T)
$$

Overall, the effect of the size of contested resources on incomes is ambiguous and depends on the degree of cooperation among the groups, which in turn can critically depend on historical contingencies. Economic factors are important but can only be a part of the story. History and elite norms of cooperation can be important as well. We provide an overview of these non-economic factors in the Bolivia in section IV. 


\section{REFERENCES}

Abadie, Alberto and J Gardeazabal, "The Economic Costs of Conflict: A CaseControl Study for the Basque Country,” American Economic Review, 2003, 93(1): 113-132.

Acemoglu, D., S. Johnson, and J.A. Robinson, Institutions as the Fundamental Cause of Long-Run Growth, in P. Aghion and S. Durlauf (eds.), Handbook of Economic Growth, Vol II., 2005, North Holland.

Albo Xavier, Thomas Greaves and Godofredo Sandoval, Chukiyawu, la cara aymara de La Paz (3 volumes), 1981, Cipca, La Paz.

Alesina, Alberto, Arnaud Devleeschauwer, William Easterly, Sergio Kurlat, and Romain Wacziarg, 2003, "Fractionalization,” Journal of Economic Growth, 8, 155-94.

CAINCO (Cámara de Industria, Comercio y Turismo de Santa Cruz) "Lo que el Estado recauda de la economía boliviana” (Msc.), 2004, Cainco, Santa Cruz.

Calderón Fernando and Roberto Laserna, El poder de las regiones. 1983. Ed. Ceres, Cochabamba,

Calderón Fernando and Alicia Smukler, La política en las calles, 2000, Ed. CeresPlural-Uasb, Cochabamba-La Paz.

Calderón Fernando and Jorge Dandler (eds.), La fuerza histórica del campesinado, 1984, Unrisd-Ceres, Cochabamba.

Collier, Paul and Anke Hoeffler (2004), Greed and Grievance in Civil War., Oxford Economic Papers, 56, 563-95.

Collier, Paul, Elliott V.L., Hegre Havard, Hoeffler, Anke, Reynal-Querol, Marta, and Sambanis, Nicholas, Breaking the Conflict Trap; Civil War and Development Policy, (World Bank Policy Report), 2003, Washington, DC: World Bank and Oxford University Press.

Dunkerley James, Rebellion in the veins, Political struggle in Bolivia, 1984, Verso editions, London

Easterly, William and Ross Levine, “Africa's Growth Tragedy: Policies and Ethnic Divisions,” Quarterly Journal of Economics, November 1997, 112 (4), 1203-50.

Easterly, William, The Elusive Quest for Growth, 2001, MIT Press.

Garfinkel, Michelle R. and Stergios Skaperdas, "Economics of Conflict: An Oveview,” in T. Sandler and K. Hartley (eds.), Handbook of Defence Economics, Vol. II, 649-709, 2007, North Holland.

Gellner, Ernest, Nations and Nationalism, 1983, Ithaca, NY: Cornell University Press.

Gonzalez, Francisco M., Insecure property and technological backwardness, Economic Journal, 2005, 115, 703-721.

Greif, Avner, Institutions and the Path to the Modern Economy: Lessons from Medieval Trade, 2006, New York: Cambridge University Press.

Grossman, Herschel I., A general equilibrium model of insurrections, American Economic Review, 1991, 81:912-921

Grossman, Herschel I. and Minseong Kim, “Predation and Accumulation,” Journal of Economic Growth, 1996, 3(1): 333-350.

Haavelmo, Trygve, A Study in the Theory of Economic Evolution, 1954, NorthHolland, Amsterdam

Hess, Greg D., The economic welfare cost of conflict: an empirical assessment, 2003, CESifo Working paper no. 852, Munich, Germany. 
Hirshleifer, Jack, Conflict and rent-seeking success functions: Ratio vs. difference models of relative success, Public Choice, 1989 63:101-112.

Hirshleifer, Jack, The paradox of power, Economics and Politics, 1991, 3:177-200.

Hurtado Javier, El Katarismo, 1986, Ed Hisbol, La Paz.

Jia, Hao, “A Stochastic Derivation of Contest Success Functions,” 2005, University of California, Irvine.

Klein Herbert, Orígenes de la Revolución Nacional, 1968, Ed. Juventud, La Paz.

Laserna Roberto, "Movimientos sociales regionales. Apuntes para la construccion de un campo empirico". Pensamiento Iberoamericano 10, 1987, Madrid.

Laserna Roberto, 20 (mis)conceptions on coca and cocaine. Ed. Clave, 1997, La Paz.

Laserna Roberto, Ciudades y pobreza, 2005, Ed. Umss, Cochabamba.

Laserna Roberto, La democracia en el ch'enko, 2004, F. Milenio, La Paz.

Laserna, Gordillo and Komadina, La trampa del rentismo, 2006, Ed. Fundacion Milenio, La Paz.

Lavaud Jean Pierre, El embrollo boliviano. Turbulencias sociales y desplazamientos políticos, 1998, Ed Ifea-Cesu-Hisbol, La Paz,

Lee, Jaewoo and Stergios Skaperdas, "Workshops or barracks? productive versus enforcive investment and economic performance,” in M.R. Baye, ed.,

Advances in Applied Microeconomics, vol. 7, 1998, JAI Press, Stamford, CT.

Loayza Bueno Rafael, Halajtayata, Etnicidad y racismo en Bolivia, 2004, Ed. Fundemos, La Paz.

Lora Guillermo, Historia del Movimiento Obrero (4 volumes 1967, 1969, 1970, 1980). Los Amigos del Libro, Cochabamba

Malloy James, La revolución inconclusa, 1989, Ed. Ceres, Cochabamba.

Mehlum, Halvor, Karl Ove Moene and Ragnar Torvik, "Institutions and the Resource Curse,” Economic Journal, January 2006, 116(508), 1-20.

Miguel, Edward, Shanker Satyanath and Ernest Sergenti, "Economic Shocks and Civil Conflict: An Instrumental Variables Approach,” Journal of Political Economy, 2004, 112(4), 725-753.

North, Douglass C., Institutions, Institutional Change, and Economic Performance, 1990, New York: Cambridge University Press.

Olson, Mancur, Power and Prosperity, 2000, New York: Basic Books.

Rivera Silvia, Oprimidos pero no vencidos, luchas del campesinado aymara y quechua 1900-1980, 1984, Hisbol, La Paz

Robinson, James A.,The Political Economy of Decentralization in Bolivia, 2005.

Roca Jose Luis (1980) Fisonomía del regionalismo boliviano. Ed. Los Amigos del Libro, Cochabamba-La Paz.

Rodrik, Dani, The New Global Economy and Developing Countries: Making Openness Work, 1999, Washington DC: Overseas Development Council.

Sachs, J.D., The End of Poverty: Economic Possibilities for Our Time, 2005, Penguin Press.

Sanabria Harry, The coca boom and rural social change in Bolivia, The University of Michigan Press, Ann Arbor, 1993.

Skaperdas, Stergios, "Cooperation, Conflict, and Power in the Absence of Property Rights,” American Economic Review, September 1992, 82(4): 720-739. 
Skaperdas, Stergios and Constantinos Syropoulos, "Insecure Property and the Efficiency of Exchange,”Economic Journal, January 2002, 112 (476), 133146.

Touraine Alain, Actores sociales y sistemas políticos en América Latina, 1987. Ed. PREALC, Santiago de Chile.

Tullock, Gordon, "Efficient Rent Seeking," in J.M. Buchanan, R.D. Tollison, and G. Tullock (eds), Toward a Theory of the Rent Seeking Society, 1980, College Station: Texas A\&M University Press: 355-372.

van Dijk, Pitou, (ed.) The Bolivian Experiment: Structural Adjustment and Poverty Alleviation, 1998, Amsterdam: Center for Latin American Research and Documentation.

Zavaleta René, Bolivia: el desarrollo de la conciencia nacional, 1970, Marcha, Montevideo 


\section{CESifo Working Paper Series}

for full list see www.cesifo-group.org/wp

(address: Poschingerstr. 5, 81679 Munich, Germany, office@cesifo.de)

2184 Pierre Dubois, Bruno Jullien and Thierry Magnac, Formal and Informal Risk Sharing in LDCs: Theory and Empirical Evidence, January 2008

2185 Roel M. W. J. Beetsma, Ward E. Romp and Siert J. Vos, Intergenerational Risk Sharing, Pensions and Endogenous Labor Supply in General Equilibrium, January 2008

2186 Lans Bovenberg and Coen Teulings, Rhineland Exit?, January 2008

2187 Wolfgang Leininger and Axel Ockenfels, The Penalty-Duel and Institutional Design: Is there a Neeskens-Effect?, January 2008

2188 Sándor Csengődi and Dieter M. Urban, Foreign Takeovers and Wage Dispersion in Hungary, January 2008

2189 Joerg Baten and Andreas Böhm, Trends of Children's Height and Parental Unemployment: A Large-Scale Anthropometric Study on Eastern Germany, 1994 2006, January 2008

2190 Chris van Klaveren, Bernard van Praag and Henriette Maassen van den Brink, A Public Good Version of the Collective Household Model: An Empirical Approach with an Application to British Household Data, January 2008

2191 Harry Garretsen and Jolanda Peeters, FDI and the Relevance of Spatial Linkages: Do third Country Effects Matter for Dutch FDI?, January 2008

2192 Jan Bouckaert, Hans Degryse and Theon van Dijk, Price Discrimination Bans on Dominant Firms, January 2008

2193 M. Hashem Pesaran, L. Vanessa Smith and Takashi Yamagata, Panel Unit Root Tests in the Presence of a Multifactor Error Structure, January 2008

2194 Tomer Blumkin, Bradley J. Ruffle and Yosef Ganun, Are Income and Consumption Taxes ever really Equivalent? Evidence from a Real-Effort Experiment with Real Goods, January 2008

2195 Mika Widgrén, The Impact of Council's Internal Decision-Making Rules on the Future EU, January 2008

2196 Antonis Adam, Margarita Katsimi and Thomas Moutos, Inequality and the Import Demand Function, January 2008

2197 Helmut Seitz, Democratic Participation and the Size of Regions: An Empirical Study Using Data on German Counties, January 2008 
2198 Theresa Fahrenberger and Hans Gersbach, Minority Voting and Long-term Decisions, January 2008

2199 Chiara Dalle Nogare and Roberto Ricciuti, Term Limits: Do they really Affect Fiscal Policy Choices?, January 2008

2200 Andreas Bühn and Friedrich Schneider, MIMIC Models, Cointegration and Error Correction: An Application to the French Shadow Economy, January 2008

2201 Seppo Kari, Hanna Karikallio and Jukka Pirttilä, Anticipating Tax Change: Evidence from the Finnish Corporate Income Tax Reform of 2005, January 2008

2202 Walter Krämer and André Güttler, On Comparing the Accuracy of Default Predictions in the Rating Industry, January 2008

2203 Syed M. Ahsan and Panagiotis Tsigaris, The Efficiency Loss of Capital Income Taxation under Imperfect Loss Offset Provisions, January 2008

2204 P. Mohnen, F. C. Palm, S. Schim van der Loeff and A. Tiwari, Financial Constraints and other Obstacles: Are they a Threat to Innovation Activity?, January 2008

2205 Sascha O. Becker and Mathias Hoffmann, Equity Fund Ownership and the CrossRegional Diversification of Household Risk, January 2008

2206 Pedro R. D. Bom and Jenny E. Ligthart, How Productive is Public Capital? A MetaAnalysis, January 2008

2207 Martin Werding, Ageing and Productivity Growth: Are there Macro-level Cohort Effects of Human Capital?, January 2008

2208 Frederick van der Ploeg and Steven Poelhekke, Globalization and the Rise of MegaCities in the Developing World, February 2008

2209 Sara Biancini, Regulating National Firms in a Common Market, February 2008

2210 Jin Cao and Gerhard Illing, Liquidity Shortages and Monetary Policy, February 2008

2211 Mathias Kifmann, The Design of Pension Pay Out Options when the Health Status during Retirement is Uncertain, February 2008

2212 Laszlo Goerke, Tax Overpayments, Tax Evasion, and Book-Tax Differences, February 2008

2213 Jun-ichi Itaya and Heinrich W. Ursprung, Price and Death, February 2008

2214 Valentina Bosetti, Carlo Carraro and Emanuele Massetti, Banking Permits: Economic Efficiency and Distributional Effects, February 2008

2215 Assar Lindbeck, Mårten Palme and Mats Persson, Social Interaction and Sickness Absence, February 2008 
2216 Gary E. Bolton and Axel Ockenfels, The Limits of Trust in Economic Transactions Investigations of Perfect Reputation Systems, February 2008

2217 Hartmut Egger and Peter Egger, The Trade and Welfare Effects of Mergers in Space, February 2008

2218 Dorothee Crayen and Joerg Baten, Global Trends in Numeracy 1820-1949 and its Implications for Long-Run Growth, February 2008

2219 Stephane Dees, M. Hashem Pesaran, L. Vanessa Smith and Ron P. Smith, Identification of New Keynesian Phillips Curves from a Global Perspective, February 2008

2220 Jerome L. Stein, A Tale of Two Debt Crises: A Stochastic Optimal Control Analysis, February 2008

2221 Michael Melvin, Lukas Menkhoff and Maik Schmeling, Automating Exchange Rate Target Zones: Intervention via an Electronic Limit Order Book, February 2008

2222 Raymond Riezman and Ping Wang, Preference Bias and Outsourcing to Market: A Steady-State Analysis, February 2008

2223 Lars-Erik Borge and Jørn Rattsø, Young and Old Competing for Public Welfare Services, February 2008

2224 Jose Apesteguia, Steffen Huck, Jörg Oechssler and Simon Weidenholzer, Imitation and the Evolution of Walrasian Behavior: Theoretically Fragile but Behaviorally Robust, February 2008

2225 Walter Krämer, Long Memory with Markov-Switching GARCH, February 2008

2226 António Afonso and Christophe Rault, What do we really Know about Fiscal Sustainability in the EU? A Panel Data Diagnostic, February 2008

2227 Sergey M. Kadochnikov and Igor M. Drapkin, Market Structure, Technological Gap and Vertical Linkage Effects from Foreign Direct Investment, February 2008

2228 Guglielmo Maria Caporale, Davide Ciferri and Alessandro Girardi, Fiscal Shocks and Real Exchange Rate Dynamics: Some Evidence for Latin America, February 2008

2229 Scott Alan Carson, Geography and Insolation in $19^{\text {th }}$ Century US African-American and White Statures, February 2008

2230 Wolfgang Buchholz and Jan Schumacher, Discounting and Welfare Analysis Over Time: Choosing the $\eta$, February 2008

2231 M. Hashem Pesaran, Christoph Schleicher and Paolo Zaffaroni, Model Averaging in Risk Management with an Application to Futures Markets, February 2008

2232 Wilhelm Kohler, Offshoring: Why Do Stories Differ?, February 2008 
2233 Stefan Bach, Giacomo Corneo and Viktor Steiner, Effective Taxation of Top Incomes in Germany, 1992-2002, February 2008

2234 Robert S. Chirinko, $\sigma:$ The Long And Short Of It, February 2008

2235 Volker Grossmann and Holger Strulik, Should Continued Family Firms Face Lower Taxes than other Estates?, February 2008

2236 Guido Tabellini, The Scope of Cooperation: Values and Incentives, February 2008

2237 Heinrich W. Ursprung and Christian Wiermann, Reputation, Price, and Death: An Empirical Analysis of Art Price Formation, March 2008

2238 Hans Fehr and Christian Habermann, Private Retirement Savings in Germany: The Structure of Tax Incentives and Annuitization, March 2008

2239 Joseph Francois and Ian Wooton, Market Structure and Market Access, March 2008

2240 Hiroyuki Kasahara and Beverly Lapham, Productivity and the Decision to Import and Export: Theory and Evidence, March 2008

2241 Gary E. Bolton and Axel Ockenfels, Does Laboratory Trading Mirror Behavior in Real World Markets? Fair Bargaining and Competitive Bidding on EBay, March 2008

2242 Atsushi Oshima, B. Ravikumar and Raymond Riezman, Entrepreneurship, Organization Capital and the Evolution of the Firm, March 2008

2243 Walter Krämer and Sebastian Schich, Large-Scale Disasters and the Insurance Industry, March 2008

2244 Leif Danziger, Adjustment Costs, Inventories and Output, March 2008

2245 Anne van Aaken, Lars P. Feld and Stefan Voigt, Power over Prosecutors Corrupts Politicians: Cross Country Evidence Using a New Indicator, March 2008

2246 Hans-Christian Heinemeyer, Max-Stephan Schulze and Nikolaus Wolf, Endogenous Borders? The Effects of New Borders on Trade in Central Europe 1885-1933, March 2008

2247 Johannes Becker and Clemens Fuest, Tax Competition - Greenfield Investment versus Mergers and Acquisitions, March 2008

2248 Giorgio Bellettini and Hubert Kempf, Why not in your Backyard? On the Location and Size of a Public Facility, March 2008

2249 Jose Luis Evia, Roberto Laserna and Stergios Skaperdas, Socio-Political Conflict and Economic Performance in Bolivia, March 2008 